تعتبر قضية الألوهية من القضايا الثائكة والتى قـ يكثر فيها الذلل ويسهل الخطأ، وذلك لأن البحث فى هذه القضية يتعلق بأمور غيبية غير محسوسة يصعب التعبية التعبير عنها

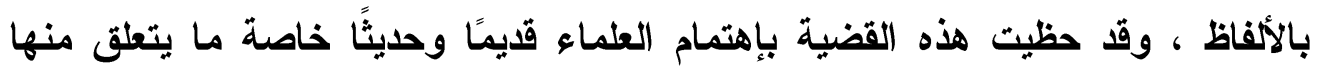

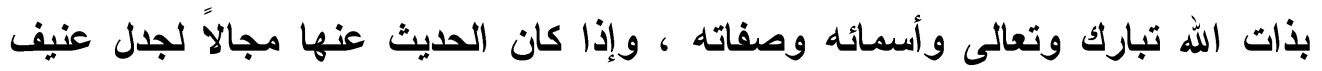
حصل بين طوائف الأمة الإسلامية ، خاصة بعد ظهور مدرسة علم الكلام والتى كاتت

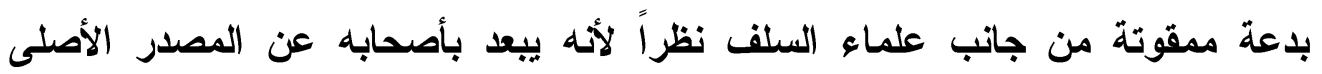

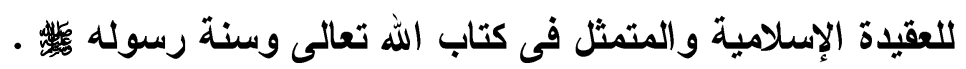

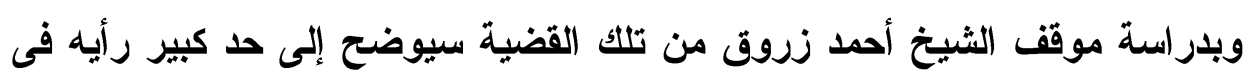
الألوهية توحيدًا وتنزيهًا ، ذللك لأن تصور الألوهية يقوم على أصلين هما: التوحيد

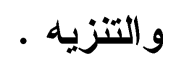
أولاً :التوحيد لاى الثيخ أحمد زروق . قبل الحديث عن التوحيد وأقسامه لابد من تعريفه لغةً و وإصطلاحًا .

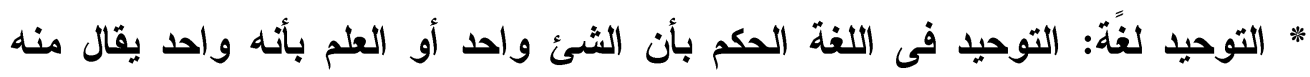

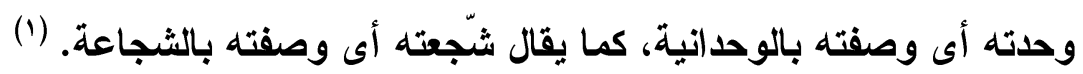

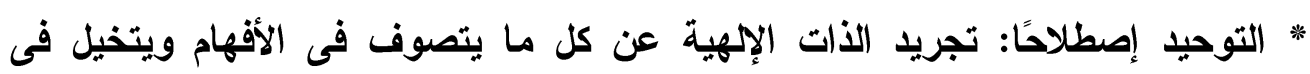

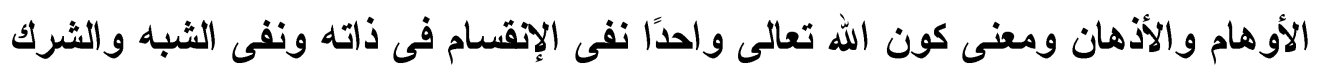

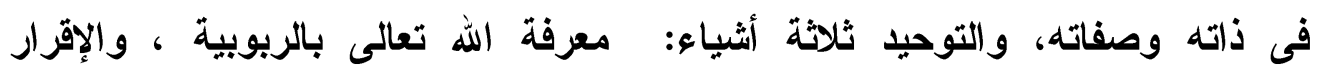

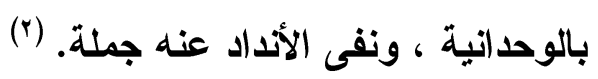

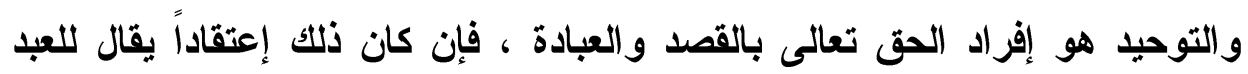

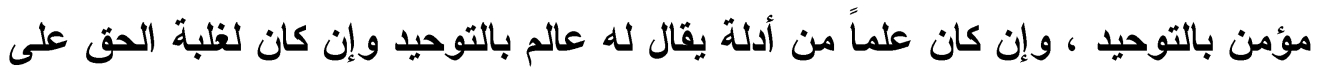
القلب واستيلائه عليه يقال أنها عارف بربه، والتوحيد هو الإيمان بالله تعالى ، والتوحيد

$$
\begin{aligned}
& \text { (') د. رفيق العجم : موسوعة مصطلحات التصوف الإسلامى - مكتبة لبنان ناشرون- بيروت- لبنان - }
\end{aligned}
$$

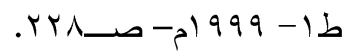

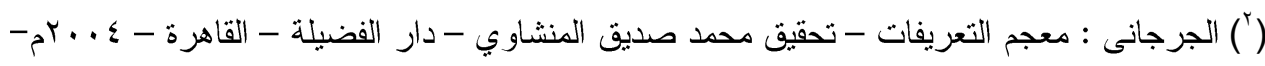

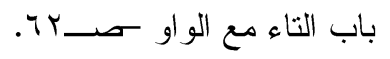


بالله تعالى درجات ومقامات، ليس إيمان موسى كإيمان بنى إسرائيل ولا إيمان عيسى

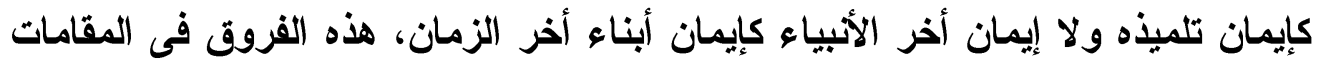
هى التى دفعت بعض العارفين بالله إلى اعتبار التوحيد درجات، توحيد العوام ، توحيا

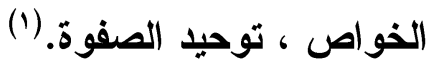

ينقسم التوحيد عند المتكلمين والفقهاء إلى قسمين توحيد الألوهية ، وتوحيد الربوبية وتقبيم التوحيد إلى الربوبية والإههية ليس بدعه بل حكاه الطبرى وغيرهم عن أهل العلم

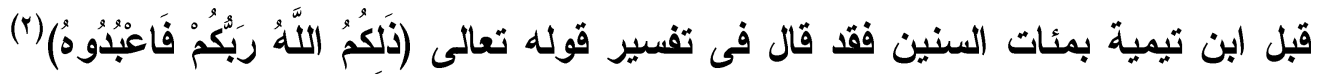

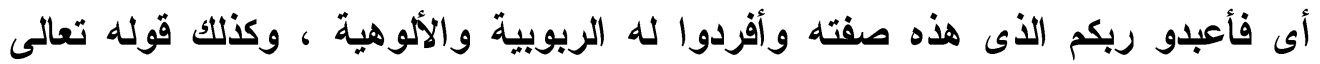

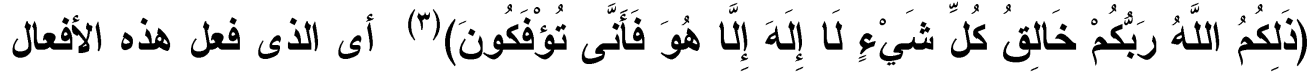

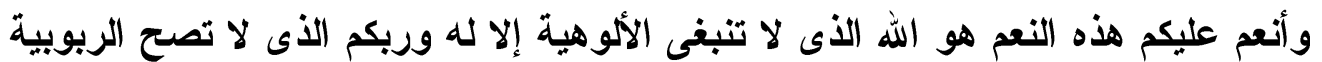

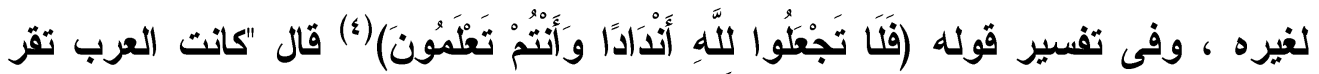
بوحدانية الله غير أنها كانت تثرك فى عبادته" فالتقسيم دليل من كتاب الله كتقسيم الأحكام إلى فرض واجب ومسنون ومباح ومكروه ومحرم وليس فى ذلك نص وإنما هو مستفاد

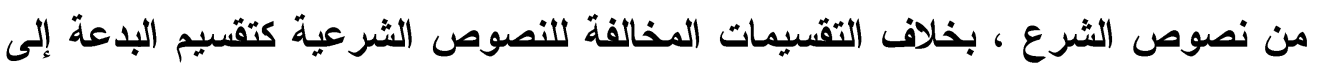

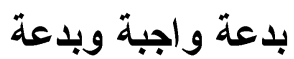

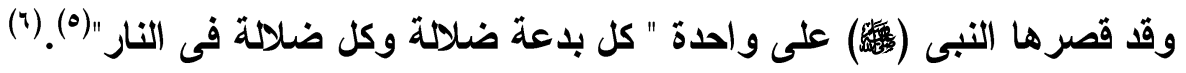

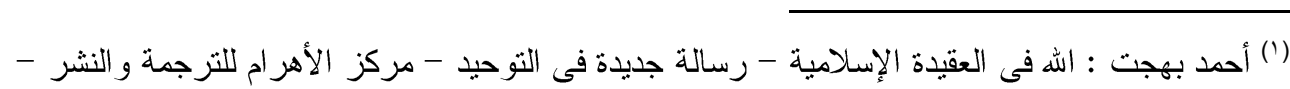

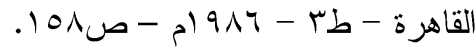

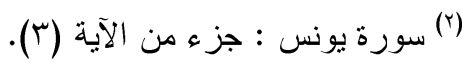

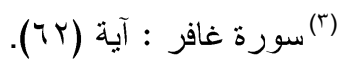

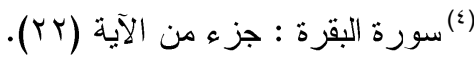

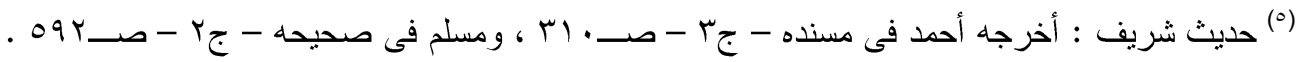
(") آعبدالرحمن سعيد : موسو عة أهل السنة فى نقد أصول فرقة الأحباش ومن و وافقهم فى أصولهم - المجلد

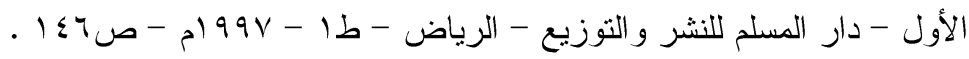




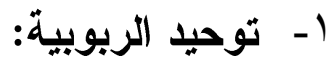

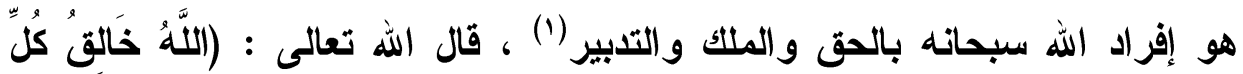

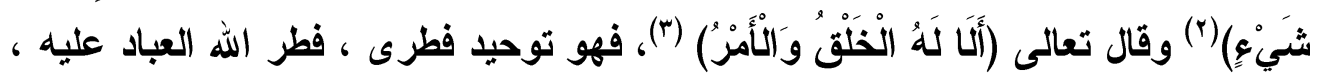

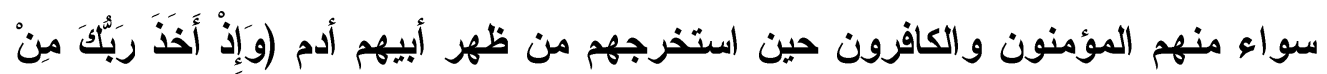

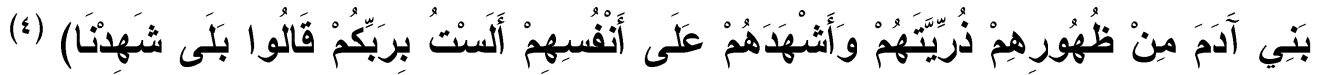

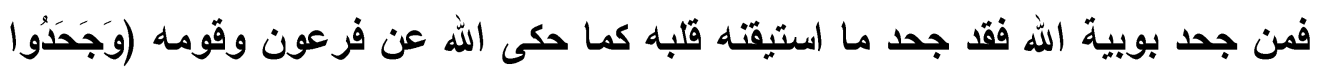

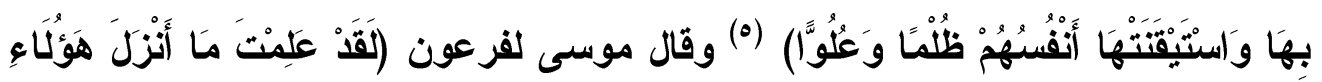

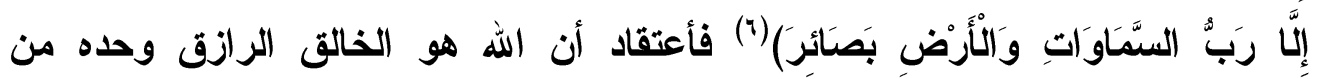
المسلمات الفطرية ولذلك يخطئ من يفنى عمره فى استخر اج الأدلة على إثبات وجود الله

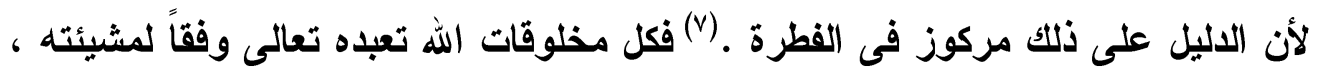
وكل شكل من أثكال العبادات تعبر عن بعض جوانب من طبيعته ـ. الثيطان نفسه يمجد

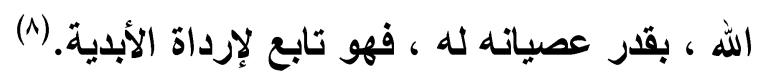

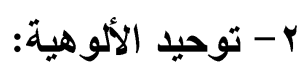

هو إفراد الله سبحانه وتعالى بالعبادة بأن لا يتخذ الإنسان مع الله أحدا يعبده ويتقرب

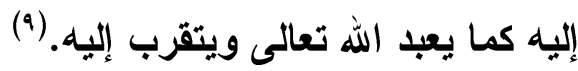

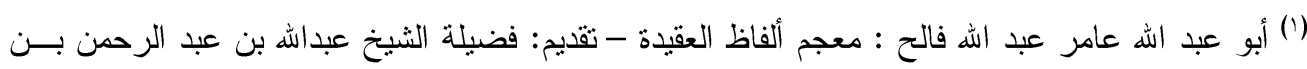

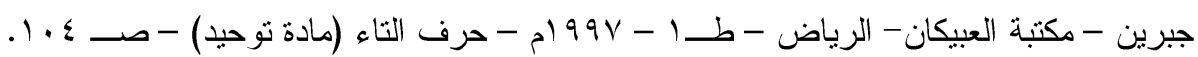
(؟) سورة الزمر : جزء من الآية (rآج).

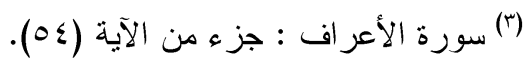

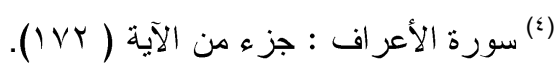

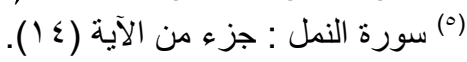

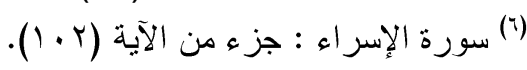

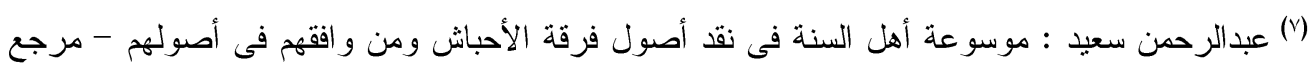

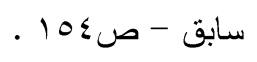
${ }^{(10)}$ R.A.Nicholoson : Studies in Islamic Mysticism - Cambridge - press - 1921 P.99.

(9) أبو عبداله عامر عبداله فالح : معجم ألفاظ العقيدة - حرف التاء (مادة توحيد) - مرجع سابق - صـ 
وتوحيد الألوهية يلخل فيه توحيد الربوبية ، بمعنى أن من أفرد الله بالدعاء والطاعة

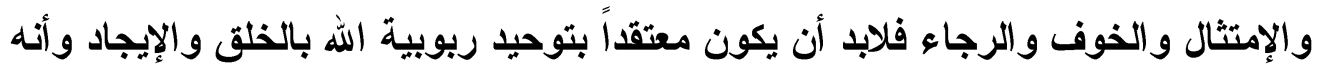

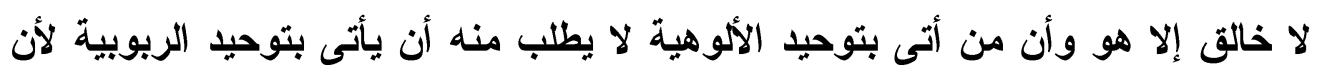

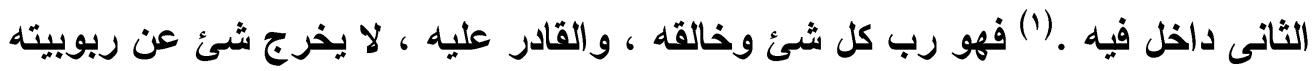

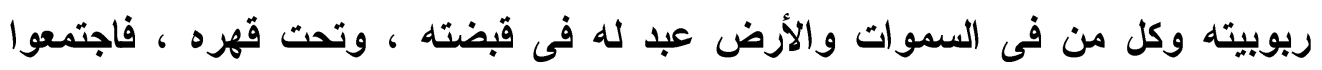

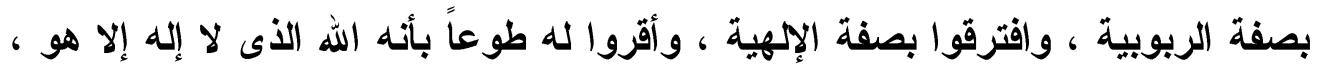
الأى لا تنبغى العبادة و التوكل ، والرجاء والخوف ، والعب والإنابة ، والخشية والتذلل

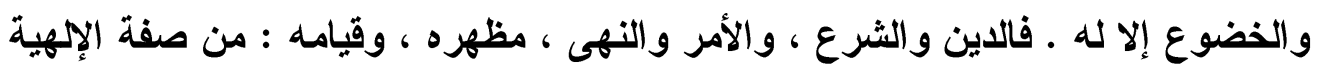

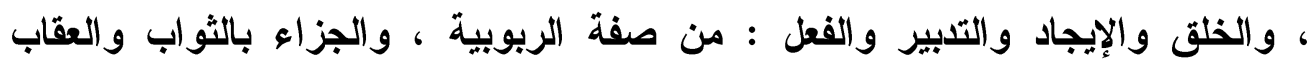

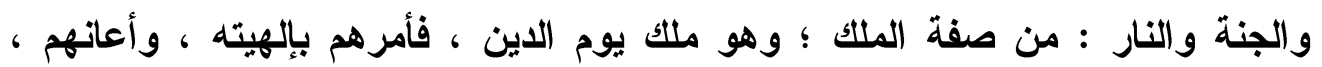
ووفقهم وهداهم ، وأضلهم بربوبيته ، وأثثابهم ، وعاقبهم بملكه وعدله وكل واحدة من ون

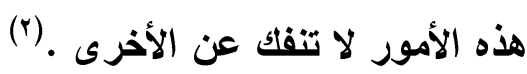
ويتضمن الإعتراف بالوحدة الأتية للإله الدق والإيمان العميق بها ، أن المسلم فى

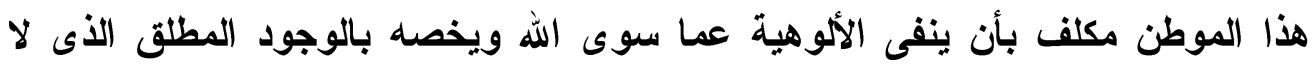

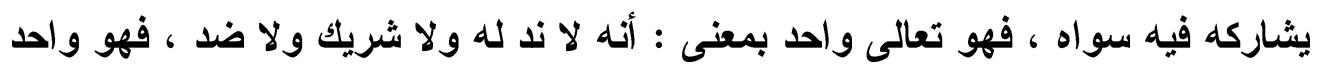

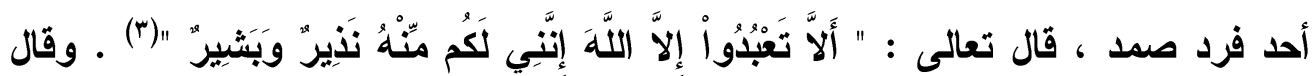

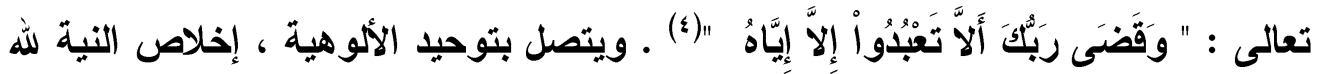

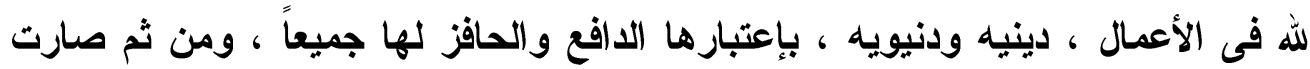

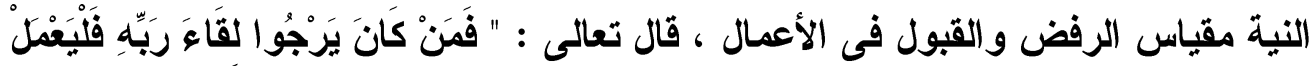

(1) عبدالرحمن سعيد : موسوعة أهل السنة فى نقد أصول فرقة الأحباش ومن و افقهم في أصولهم - مرجع .

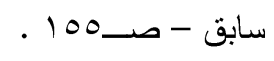

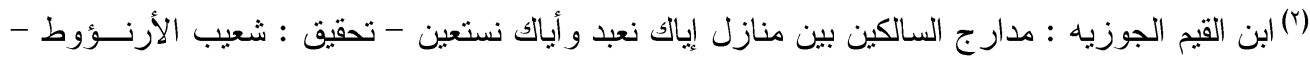

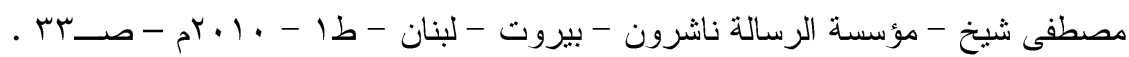

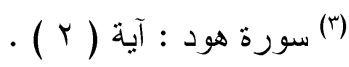

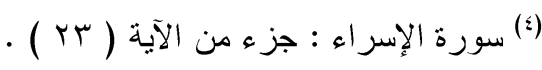




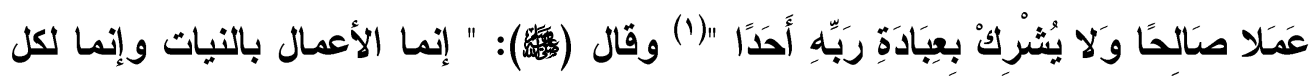

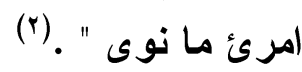
ولهذا الربط المحكم بين العمل والنية الباعث عليه أهميته إذ بموجب هذا الترابط صار

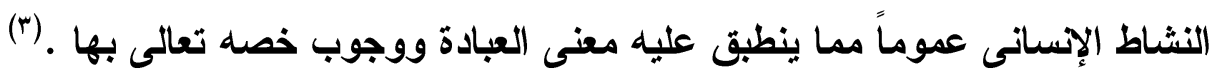

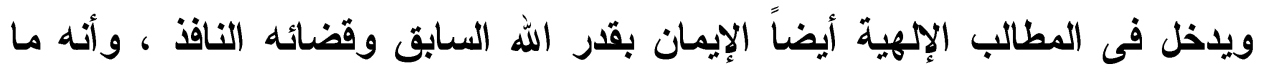

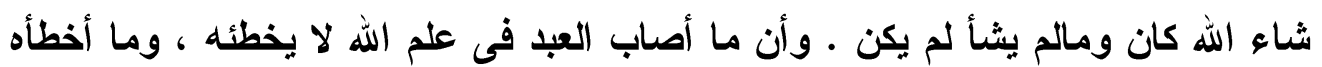

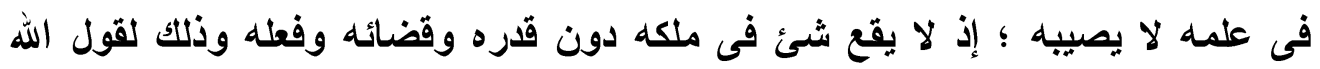

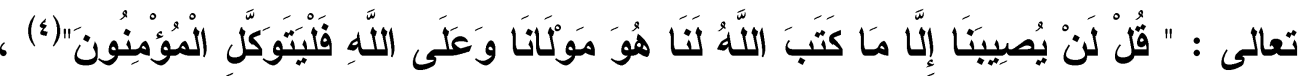

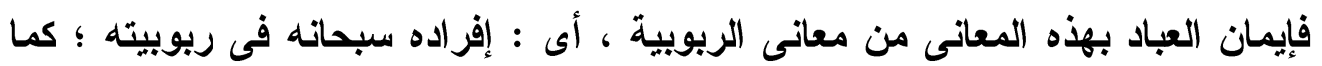

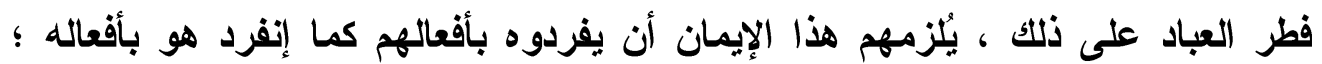

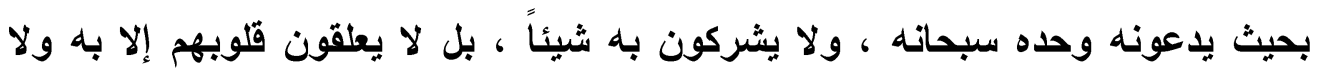

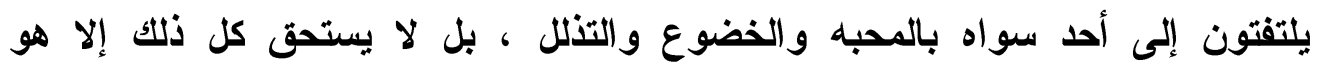

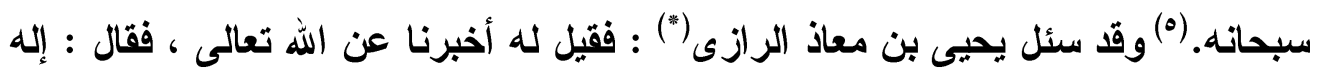

$$
\text { (1) سورة الكهف : جزء من الآية ( (11) ) : (1) }
$$

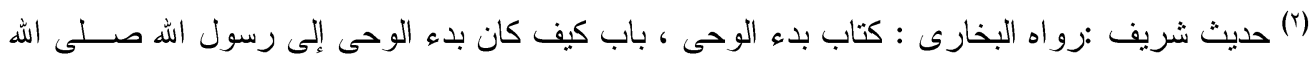

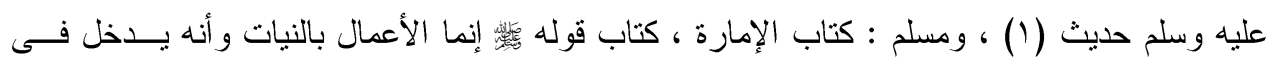

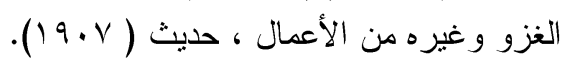

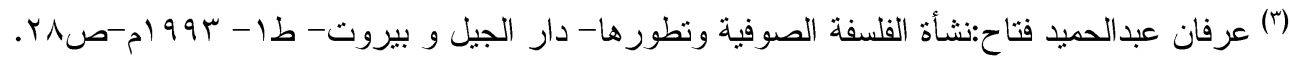

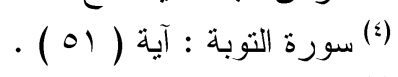

(0)محد أمان الجامى : مجموع رسائل الجامى فى العقيدة و السنة - دار ابن رجب للطبع و النشر و التوزيع

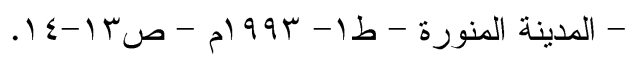

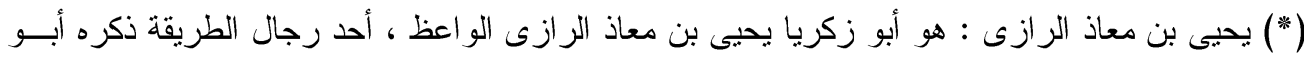

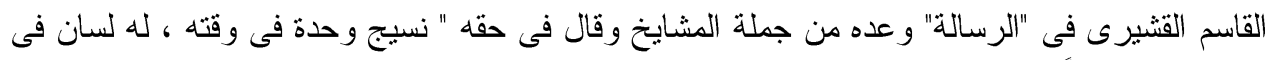

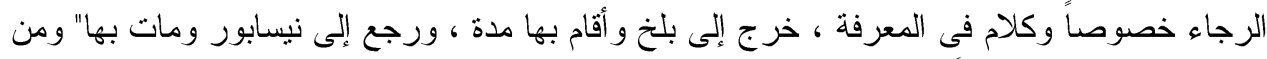

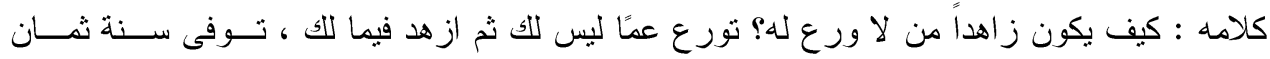

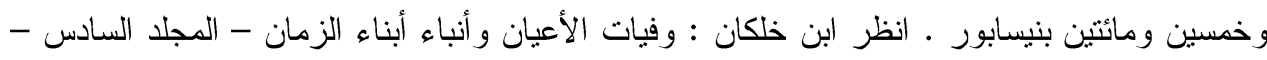

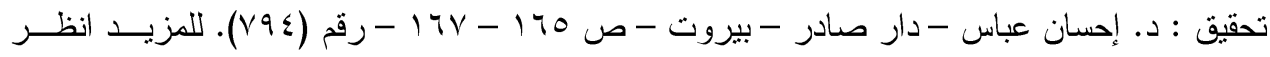

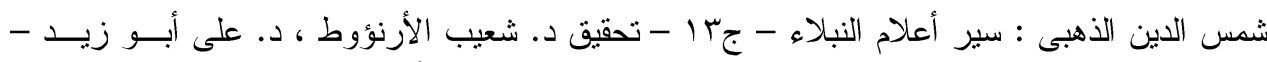

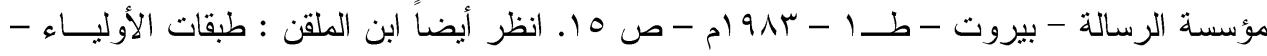


أحد ، فقيل : كيف هو ؟ فقال : إله قادر ، فقيل : فأين هو ؟ فقال : بالمرصاد ، قال

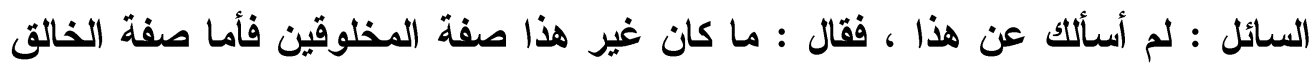

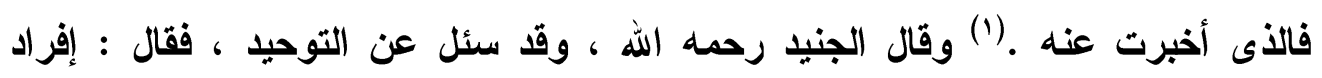
الموحد بتحقيق وحدانيته بكمال أحديته بأنه الواحد الذى لم يلد ولم يولد بنفى الأضداد

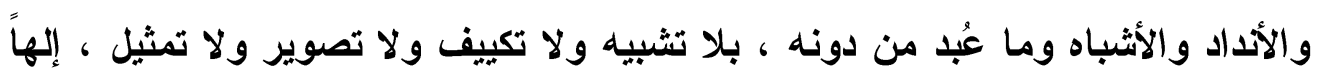

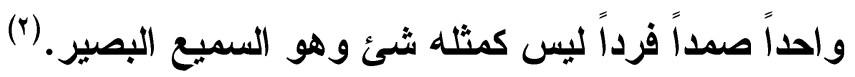
r- الألوهية و الربوبية عند الثيخ أحمد زروق : عند الحديث عن الله عز وجل يميز زروق بين جانبين اثنين هما : الألوهية والريوبية

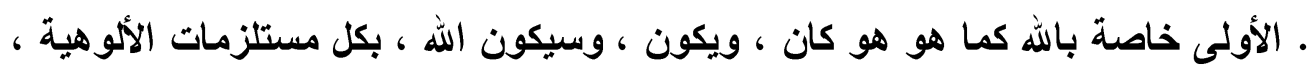

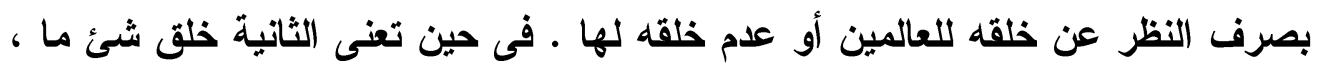

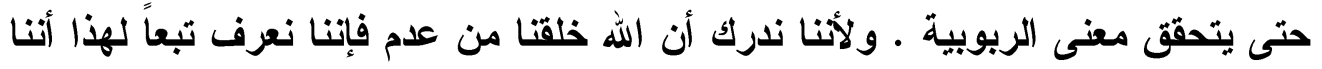

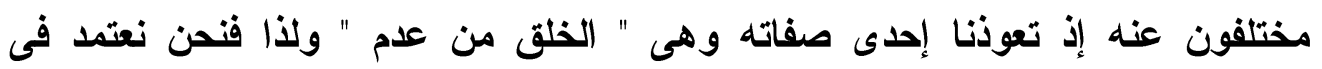

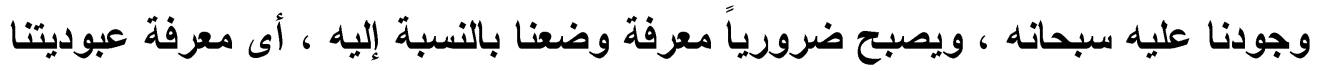

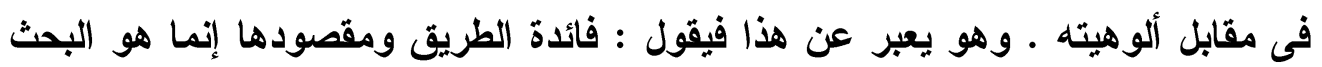

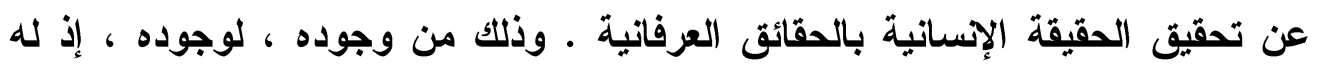

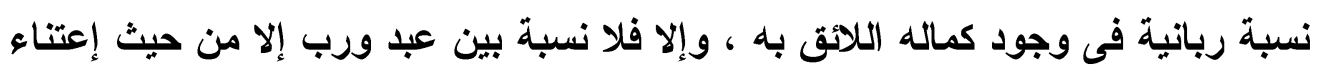

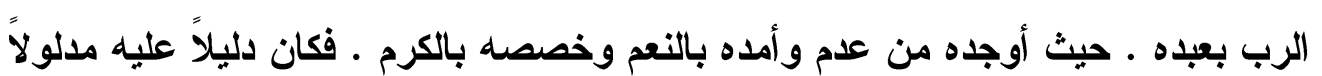

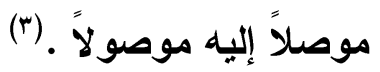

(1) منصور محمد عويس : ابن تيميه ليس سلفياً - دار النهضة العربية - القاهرة - طا - .9Vام ص1ال.

(r) أبى نصر السر اج الطوسى : اللّمُع - تحقيق : عبدالحليم محمود - طه عبدالباقى - دار الكتب الحديثة -

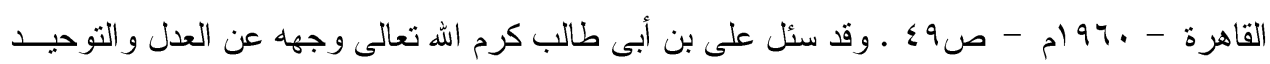

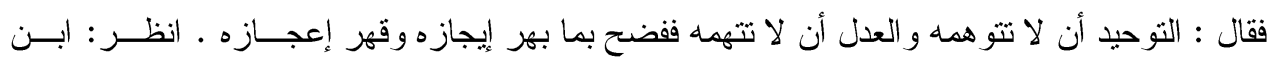

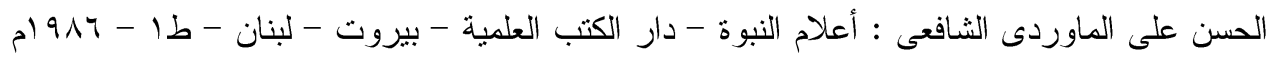
- صعا .

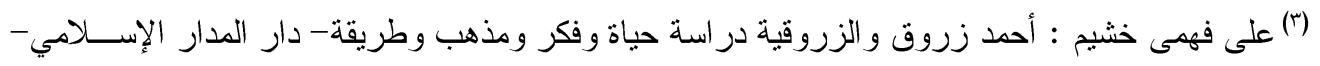

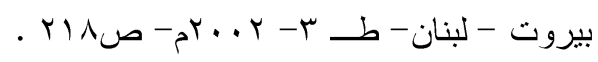


ومنذ البداية ، يقول الثيخ : تجب علينا معرفة أن الله مغاير تماماً لأى شئ نراه أو

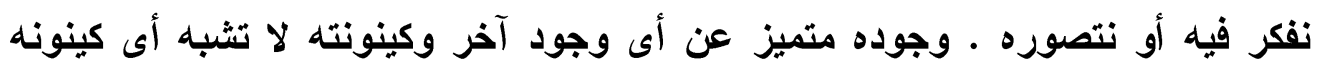

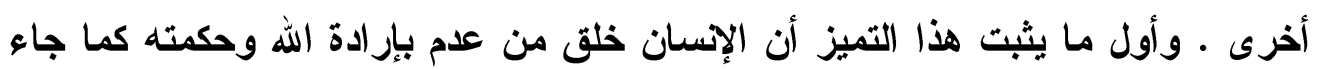

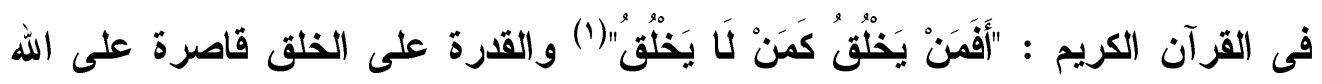

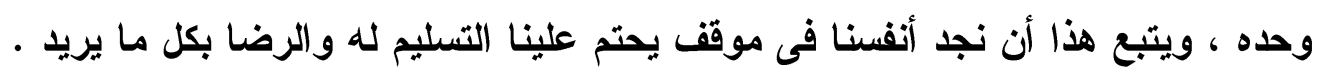

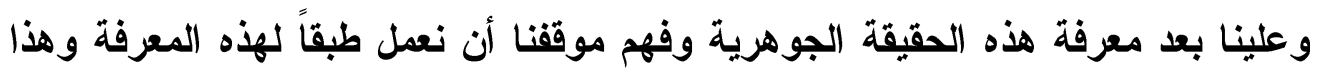

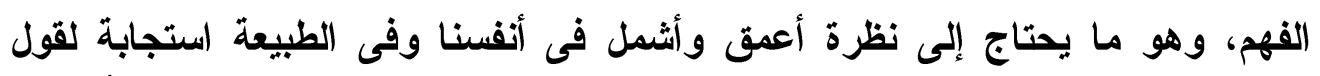

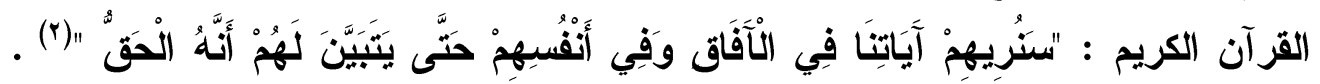
فالله هو الأى خلقنا وهو الذى يحفظ وجودنا ، و لإرادته المطلقة أن يفعل بنا وبالخلق كله النه ما يشاء ـ هذا عن الخلق والخالق ، وهى أخص صفات الله سبحانه فيما يتصل بالألوهية

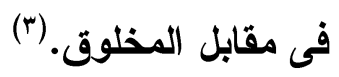

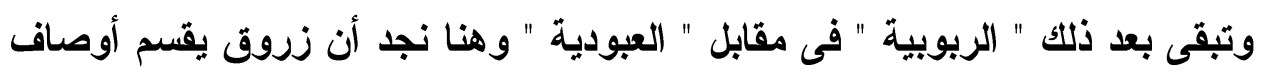

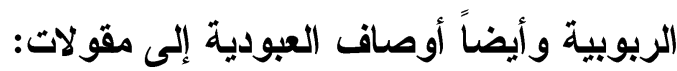

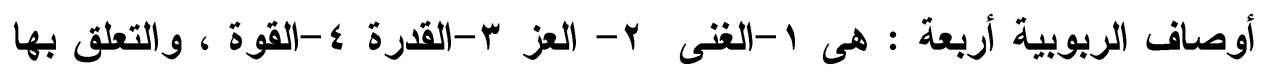

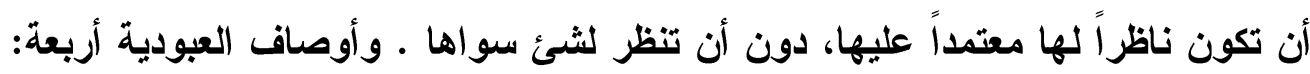

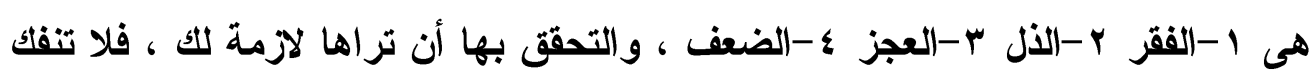

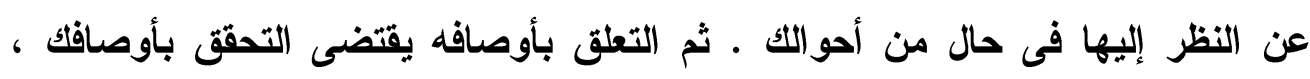

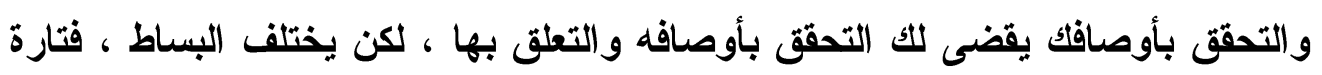

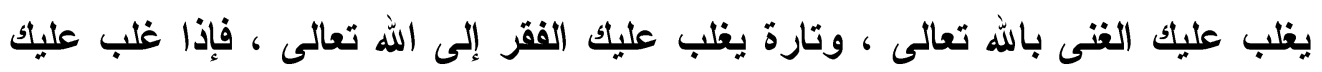

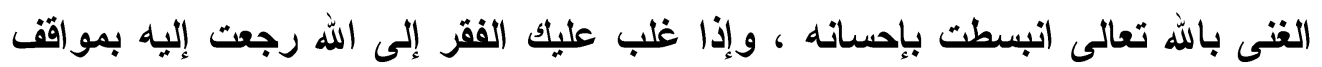

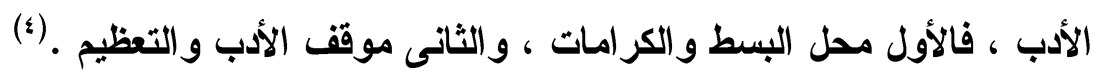

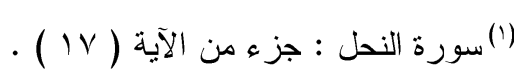

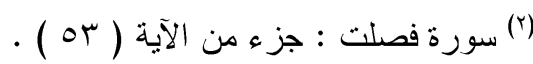

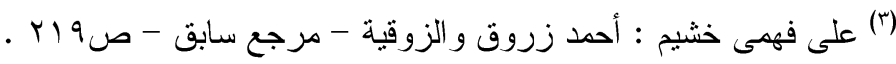

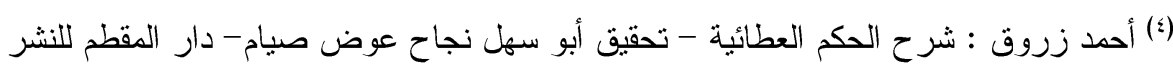

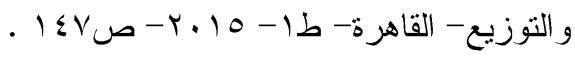


فبقدر ما يظهر على العبد آثار الأوصاف الدالة على عجزه وفقره وذله وضعفه ؛ يتبين وجود غنى الحق وعزه وقدرته وقوته ؛ فبقر ظهور آثار البشرية يقع ستر

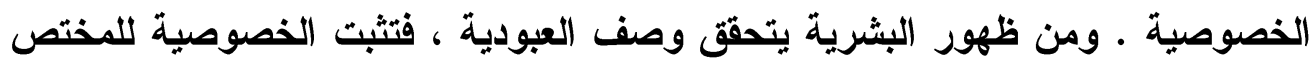
ـ ليبين وجه عظمة الريوبية ـ لذلك قال الثيخ أبو الحسن رضى الله عنه العبودية جوهرة أظهر بهالربوبية ـ فإذا تحقيق الخصوصية فى التحقق بالعبودية تبرك ما سوى الحق له له وبهـ (1) وحين يقف الإسسان موقف العبودية قبل الرب فإنه بالتالى يتخذ موقف الإنعتاق أمام الأغيار وهو يتحرر من إعتبار الآخرين ساده مصيره أو موجهى حياته وقدره ، بمجرد

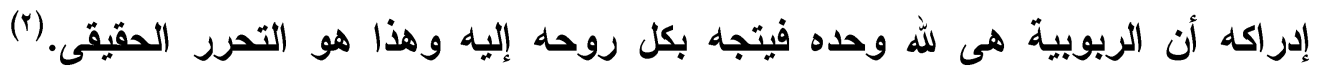
وظهور وصفه عليك وتحليك به كما يليق بك بحيث تصير غنياً به عزيزاً به ، قادراً به ،

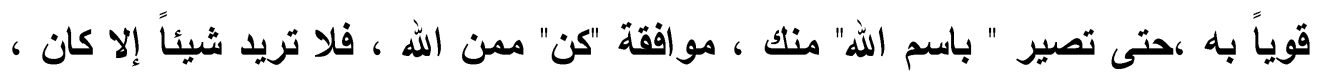
ولا تفتقر لشئ ولا تذل له ولا به ، ولا تضيز بله بله عن شئ ولا تعجز عن شئ بل تكون قادراً

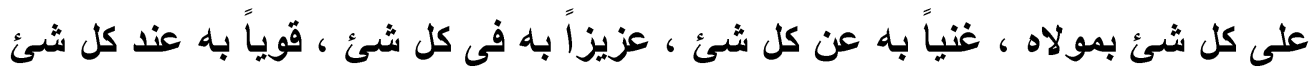

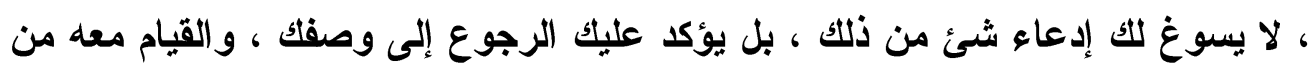

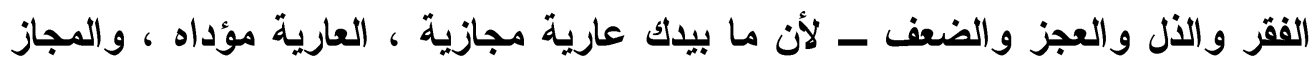

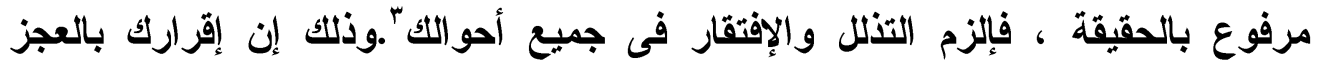

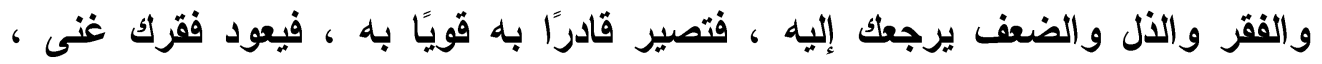

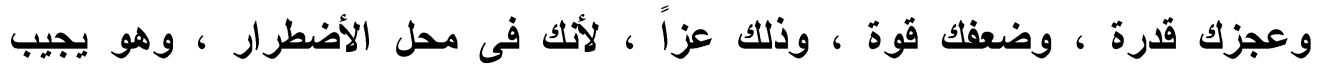

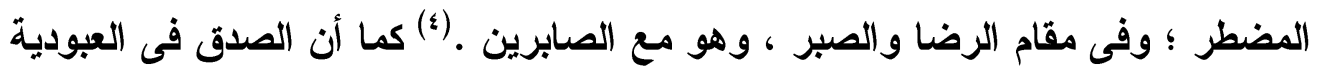

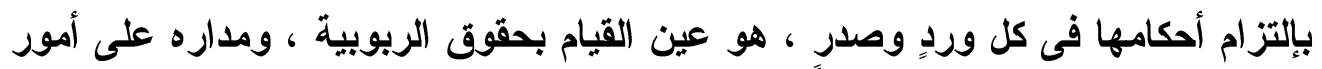
ثلاثة : التشمير للحقوق ؛ والإعراض عن كل مخلوق ؛ والإستسلام تحت جريان المقادير

$$
\begin{aligned}
& \text { (1) المرجع السابق - صهمبا . (1) }
\end{aligned}
$$

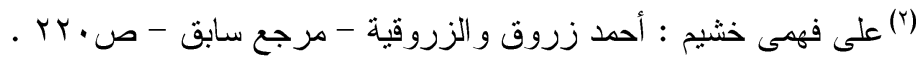

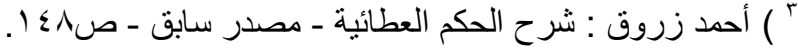

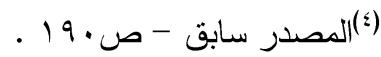


والأحكام • وقد يعبر عنه بإمتثال أمره والإستسلام لقهره ؛ أو يعبر عنه بالطاعة والغنى

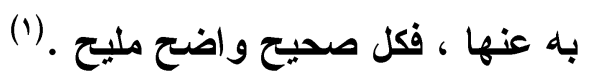
ثانياً:منهج الثيخ أحمد زروق فى الأسماء و الصفات

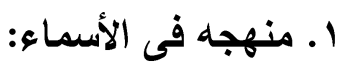

يثير القرآن فى كثير من آياته إلى أسماء الله يعرفه بهاء المؤمنون أو يدعونه بها ، ألهاء

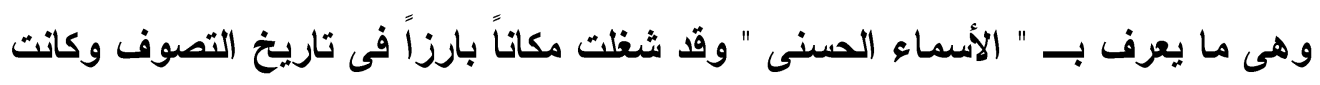
موضوعاً لعدد لا يحصى من المناقشات والمؤلفات عن طبيعة هذه الأسماء ومعانيها

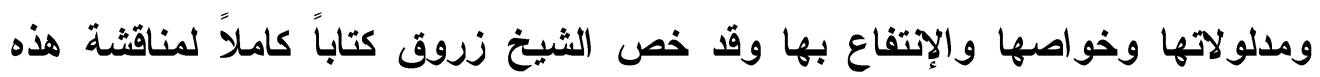

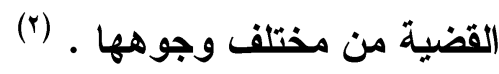

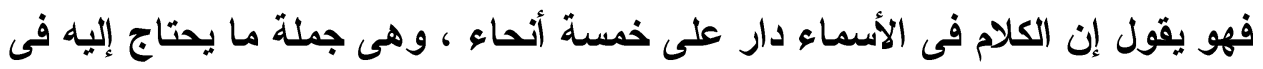

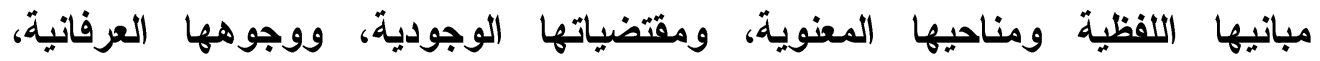
وخواصها الوجدانية ، ولكل فريق طريق.

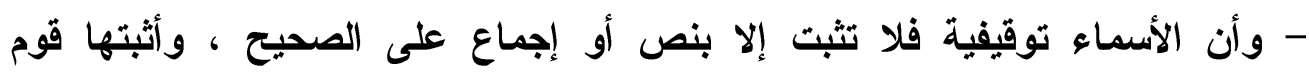

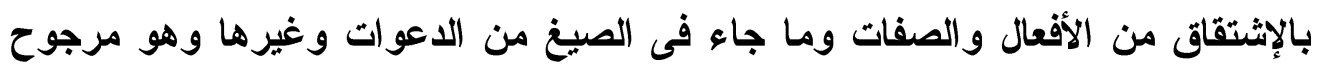
عند العلماء ملحوظ عند المتصوفة ، وعليه جرى الثيخ أبو العباس البونى (") فى ونى

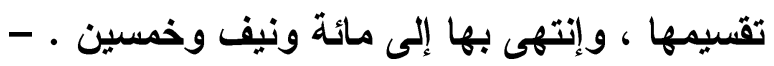

$$
\text { (1) (1) المصدر السابق : ص111) }
$$

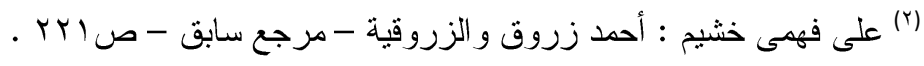

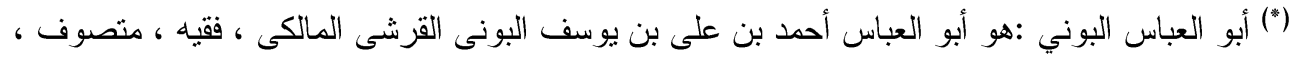

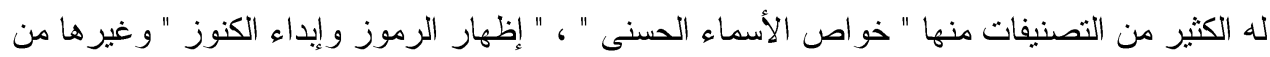

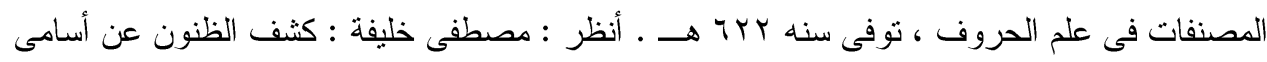

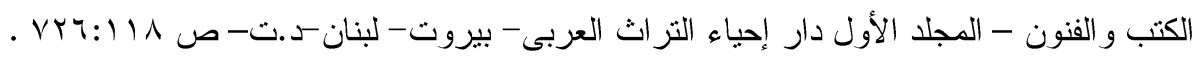


أن الأسم عين المسمى ، وأباه قوم ، وفصل آخرون ، وتوقف آخرون ، إمتناعاً لكن السلف لم يتكلموا فى الأسم والمسى ولا فئ فى الصفة والموصوف، ولافى التلاوة

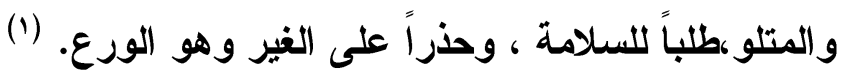

ثم قسم زروق الأسماء الحسنى من الناحية التصنيفية إلى أربعة أقسام هى العى :

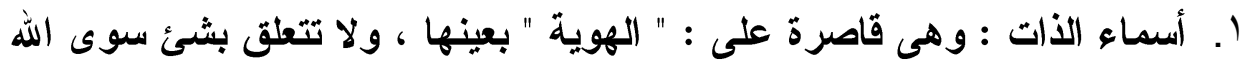

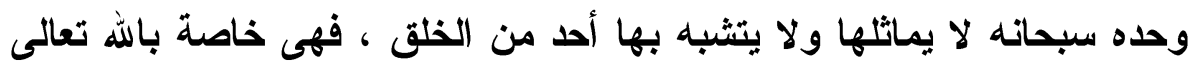

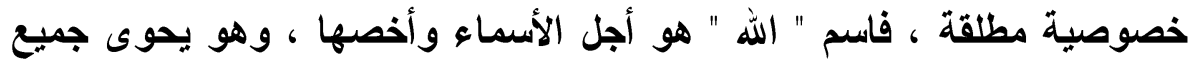

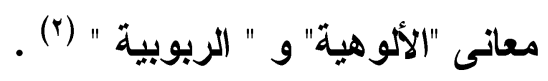

يقول زروق : كل الأسماء يصح لمعانيها التخلق إلا هذا الإسم فإنه للتعلق وكل

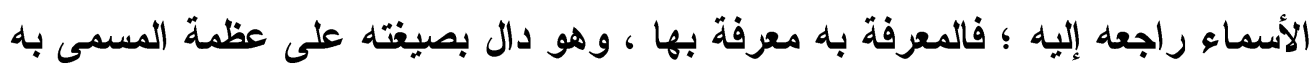

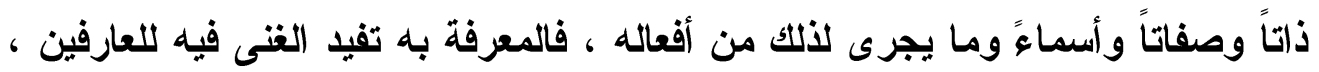

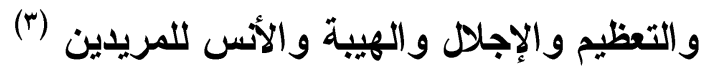
r. أسماء الصفات: وهى " لاهى هو ولاجل هى غيره ولا هى فيما بينها أغيار .

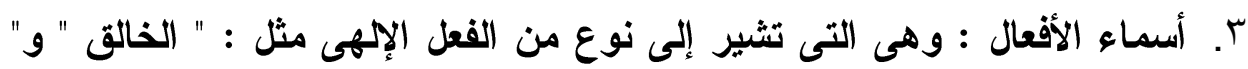

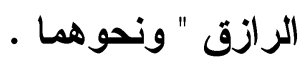
؛. أسماء التنزيه : وهى التى تلال على التنزيه المطلق للذات الإلهية مثل "القدوس" - وثمة تقسيم آخر للأسماء يجعلها فرعين أثنين : 1. الأسماء الجامعة : وهى ما يشمل أسماً آخر أو أكثر أو يحوى معناه فنحن حين

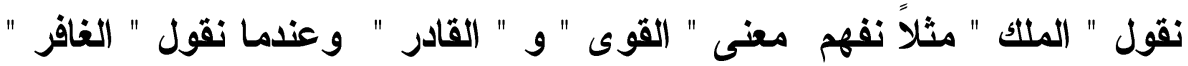
نربط الإسم بـ " الرحيم " و " اللطيف " و " الودود " .

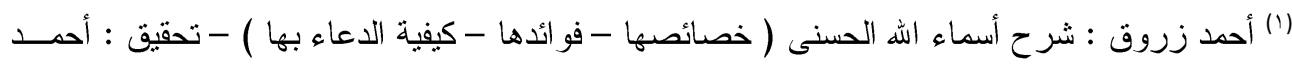

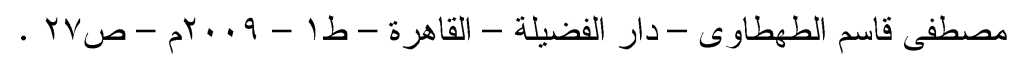

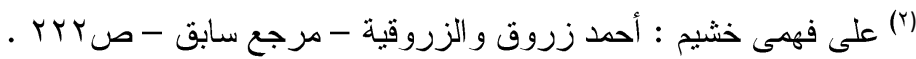

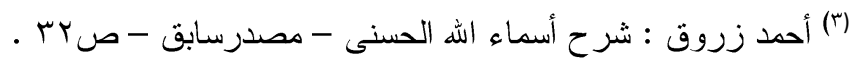


r. الأسماء الإقتصارية: وهى ما يعنى التفرد ، مثل " الواحد "و " الأحد " و " الصمد

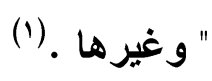

والتقسيم الثالث يقوم على أساس أن الأسماء تنقسم إلى ثلاثة أقسام :

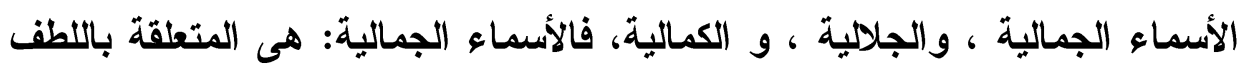
و الرحمة مثل المؤمن والسلام والودود ، والأسماء الجلالية : هى المتعلقة بالقهر والعزة

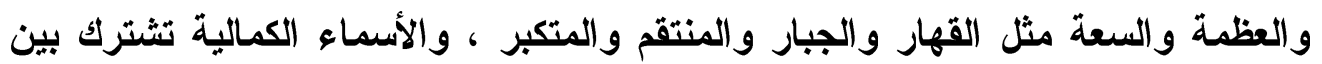

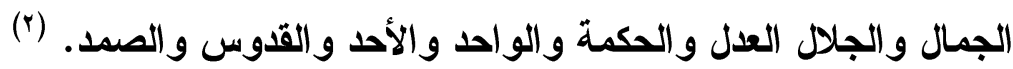
والتقسيم الرابع ينبنى على أن ثمة :

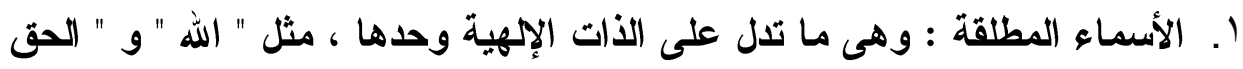

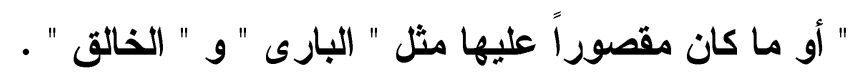
r. الأسماء المشتقة : وهى ما يثتق من أفعاله تعالى ، مثل " المصور " و " الموجد

$$
\text { " و " الكريم }
$$

و التقسيم الخامس يجعل من الأسماء :

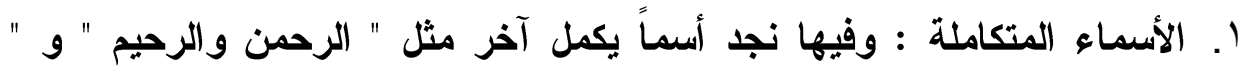

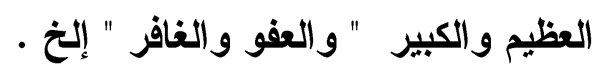

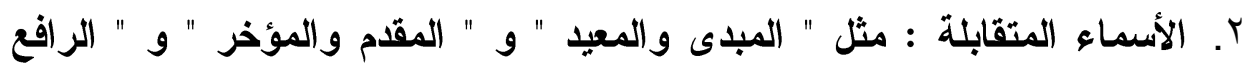

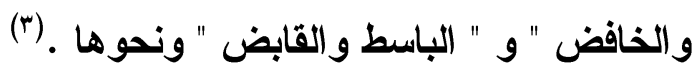

ويقدم زروق بالنسبة لأغراض الأسماء الحسنى وإستعمالها خمسة أهداف محدده عنده هی :

ا. العلم : إذ ينبغى أن نعرفها حتى نعرف الله من خلالها ، فإن من لا يعرف من

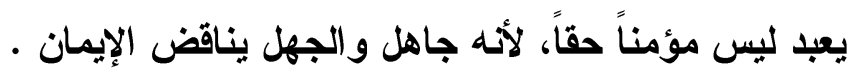

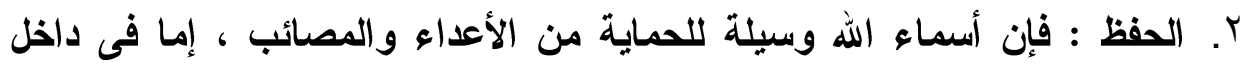
الإنسان ، كالنفس وشهواتها ، أو خارجة مما يتعرض له في حياته اليومية .

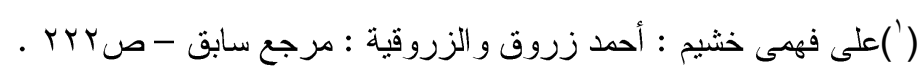

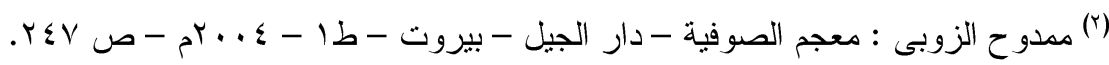

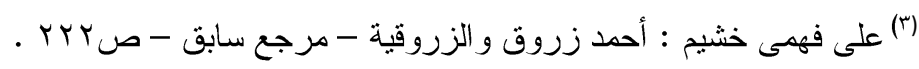


r. التعلّق : وذلك بفهم معنى الأسم و التوجه إلى الله بحسب هذا المعنى فعندما نعرف

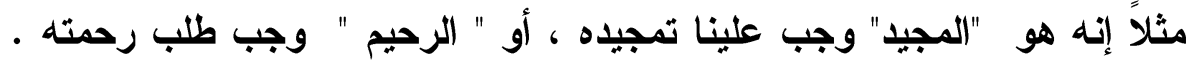

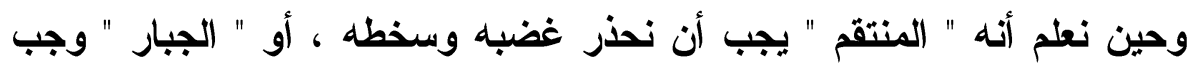

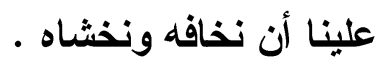
؟. التحقق والتخلق : وهذا ينطبق على موقفنا تجاه أنفسنا وتجاه الآخرين واللطف

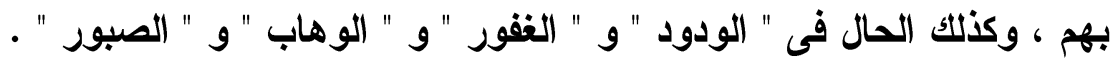
و إذا كان " التعلق " فى حقيقته هو موقف العبد أمام الله حيث لا شئ يعتبر حقاً ماعدا فوداب تمجيده تعالى ، فإن " التخلق " هو تأثر العبد بإسم الذات الإلهية حتى يفقد وعيه بغير

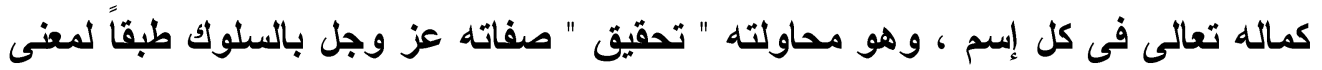

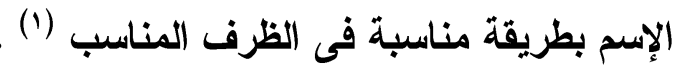
r . منهجه فى الصفات :

لا يختلف منهج زروق فى الصفات عما ذهب إليه السلف وأهل السنة و الجماعة . يقول زروق فى مقدمه كتابه ( إغتنام الفو ائد ) : - " فتصحيح العقيدة بالإيضاح و البيان ،

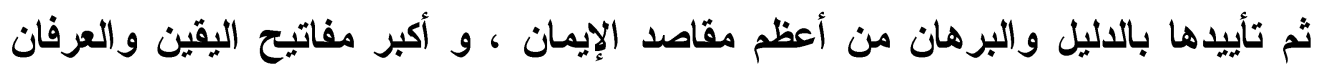

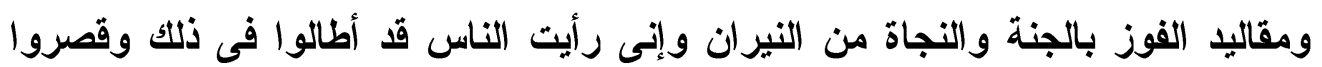
وبسطوا واختصروا فلم أرى مثل عقيدة حجة الإسلام ، لما إحتوت عليه من من التهان التحرير

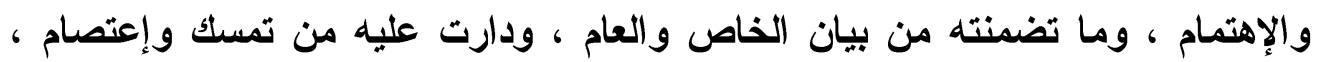

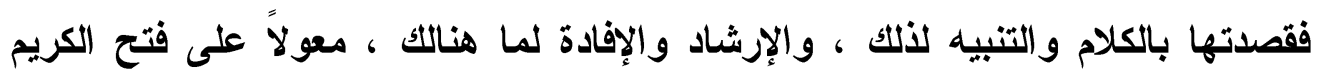

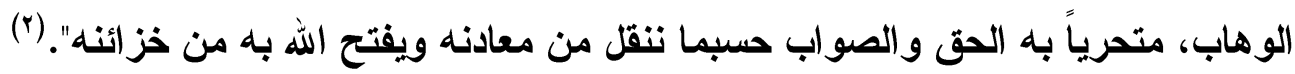
ويقسم " زروق " الصفات الإلهية إلى أربعة أقسام :

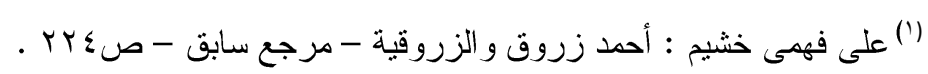

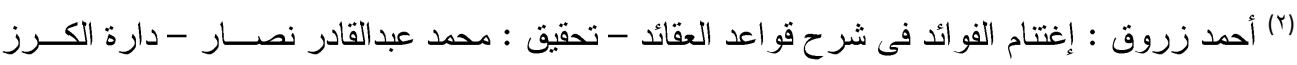

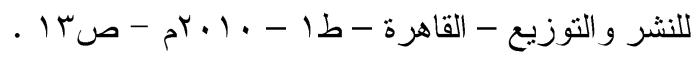


ا ـ صفات الأات : وهى تثقسم إلى إثنين :

أ. الصفة النفسية : الوجود

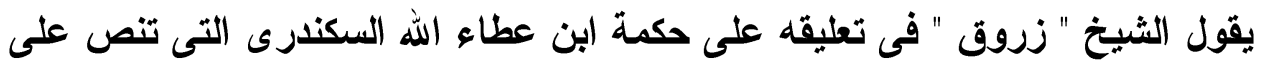

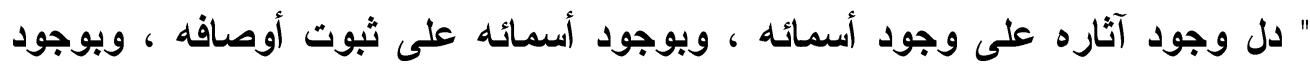

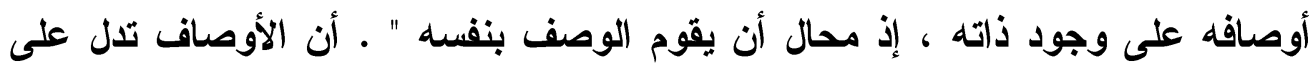

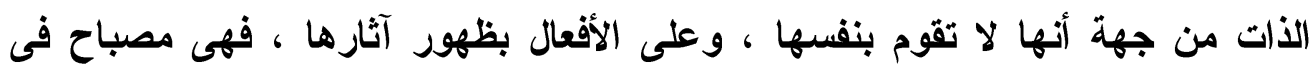

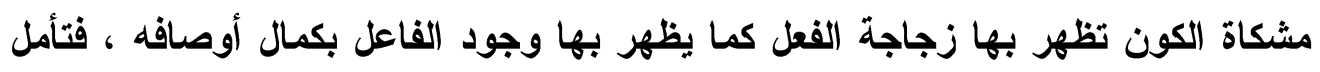

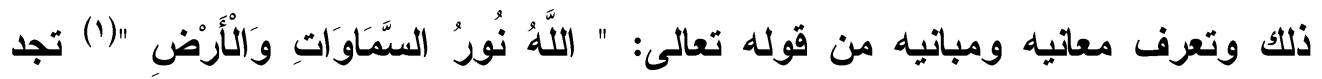

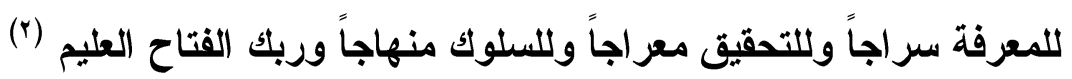

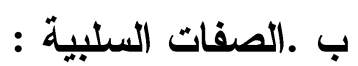

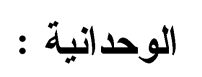

يقول زروق إذا ثبت وجوده فهو واحد من جميع جهات الوحدانية : واحد فى ذاته لا

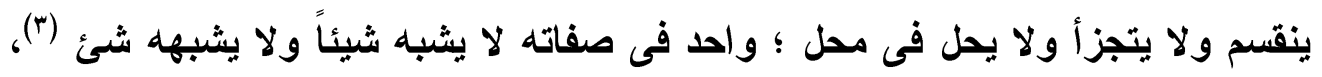

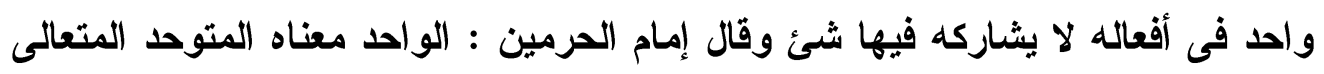
عن الإقسام .(๕) وقال إبن فورك : الواحد فى وصفه تعالى له ثلاثة معان ، ولفظه الواحد

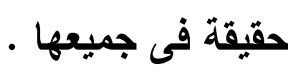
أحدهما : أنه لا قسيم لذاته وأنه غير متبعض • أنه ولا متحيز .

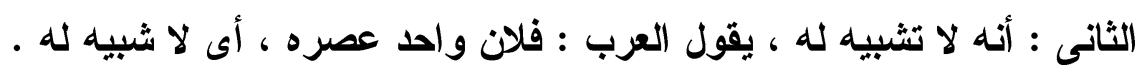

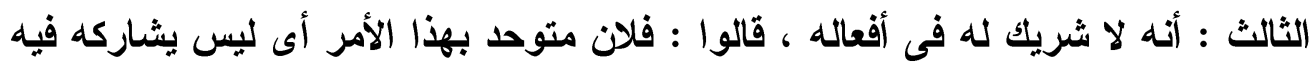

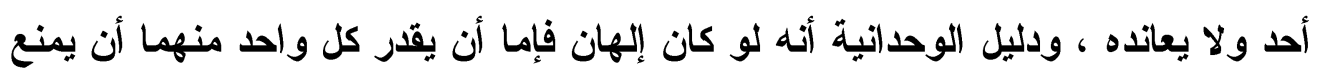

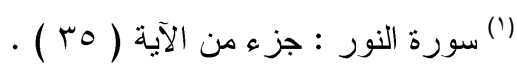

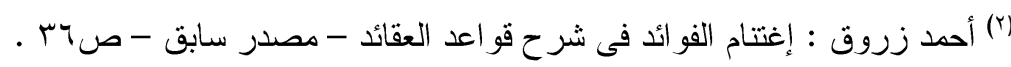

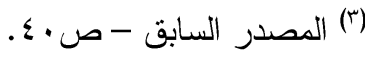

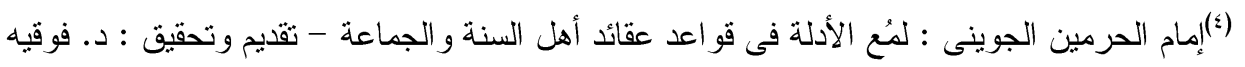

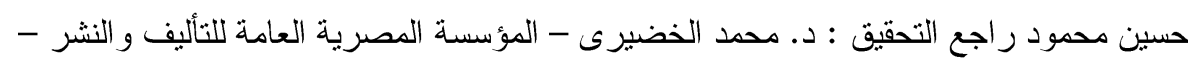

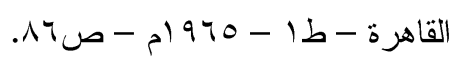


الآخر مما يريد ، أو يقر أحدهما دون الآخر ، أو يتفقا ، والكل باطل للزوم جواز العجز

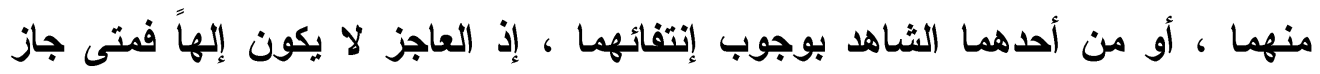

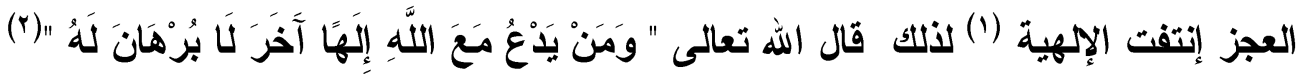
وفى شرح لقول الإمام الفزالى ( صمد لا ضد له ) يقول زروق : الصمد الأى يصُّد

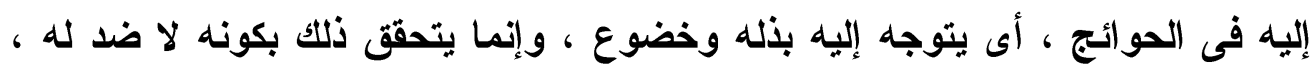

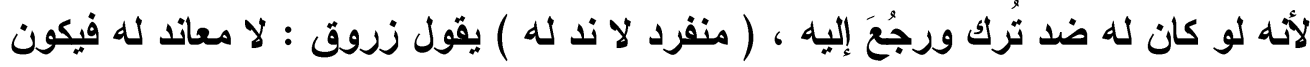

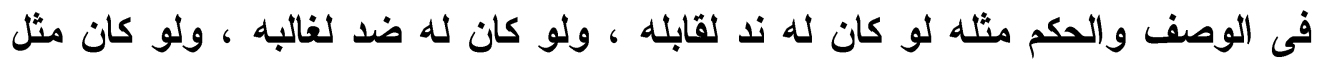

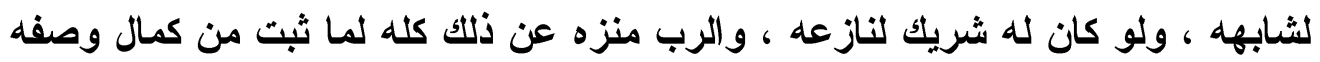

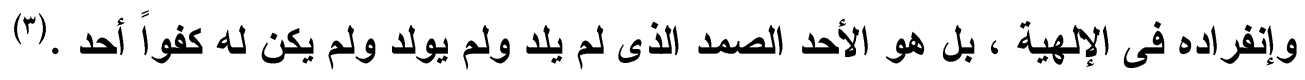
• القدم القد

قال الثيخ زروق فى شرحه لقول الإمام الغزالى ( واحد قديم لا أول له ) يعنى أنه

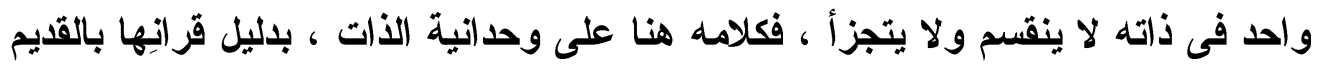

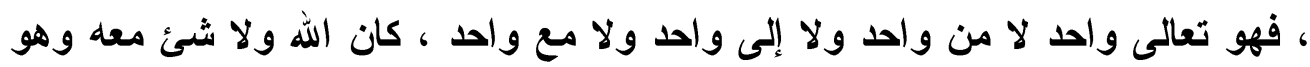

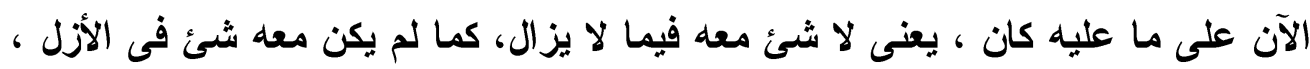

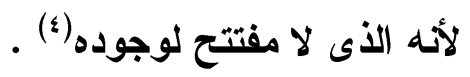
البقاء : البقاء

يقول زروق فى شرحه لقول الإمام الغزالى ( مستمر الوجود لا أخر له ) ، فلا يصح

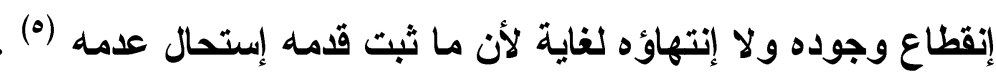

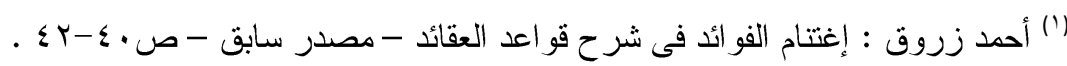

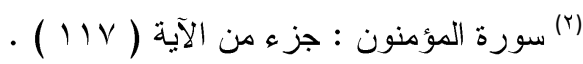

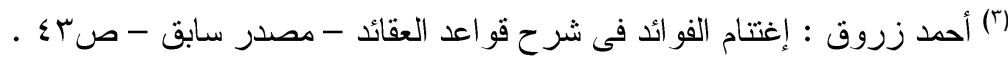

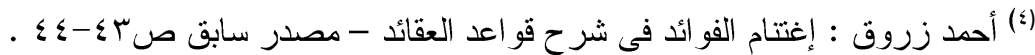

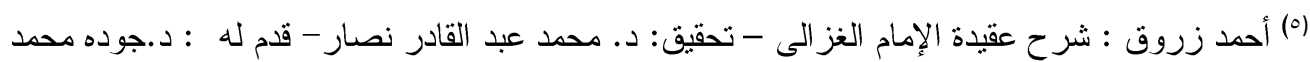

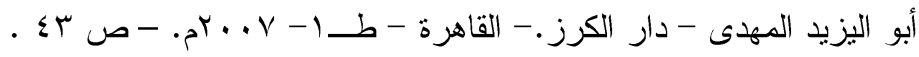




\section{القيام بالنفس :}

يقول زروق : أى قائم بنفسه وقائم بأمور خلقه ، و القيوم والقيام بمعنى واحد ، وقد

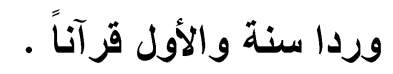

قال الثيخ أبو إسحاق الأسفراينى : والقيام عند المتكلمين المستغنى عن المحل و المخصص ، وقال ابن عباس رضى الله عنه : القيوم الذى لا تفنيه الدهور ولا يغيره

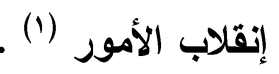

r. صفات المعانى : وهى سبع ، الحياة والقدرة والعلم والإرادة والسمع والبصر

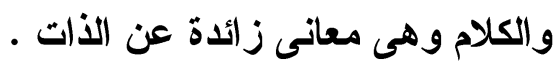

أ. الحياة والقدرة : يقول الثيخ زروق القدرة هى الصفة المقتضية لإبراز الجائز

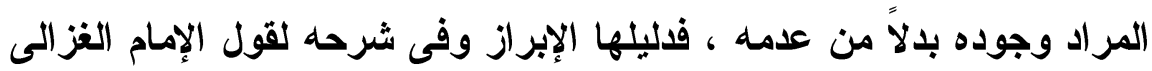

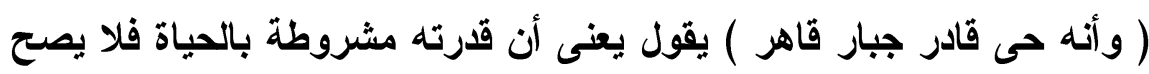

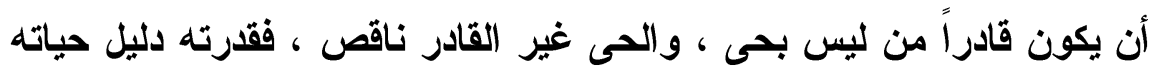

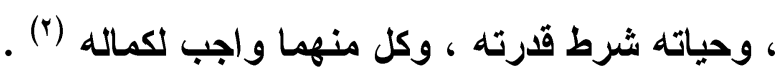

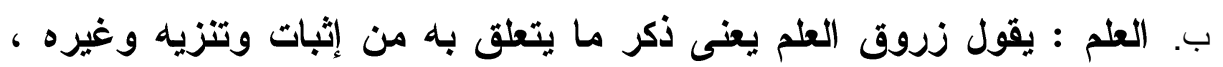

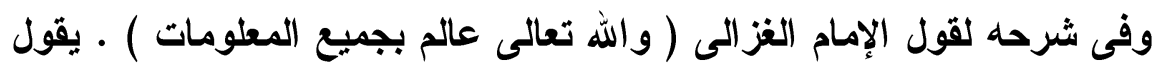

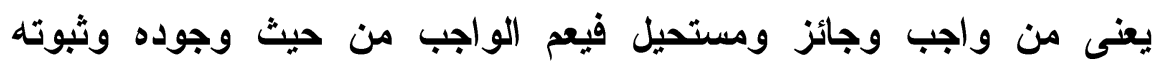

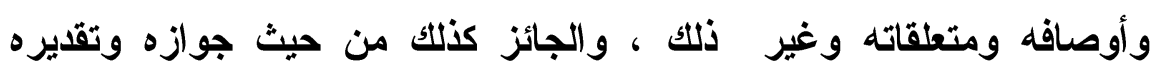

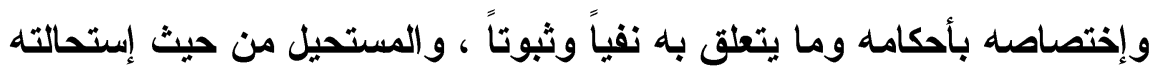
وحكمه وما يترتب عليه أن لو قدر وقوعه ، كان بان عقلياً أو شرعياً أو عادياً

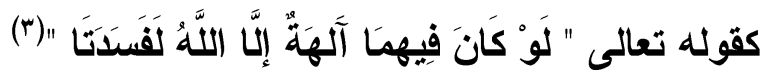

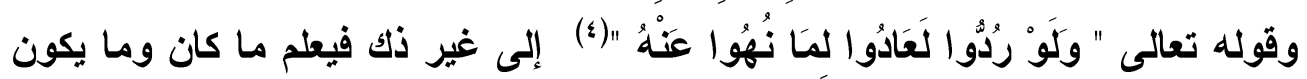

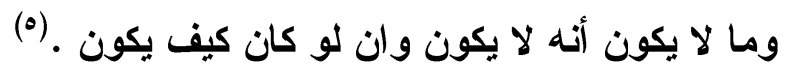

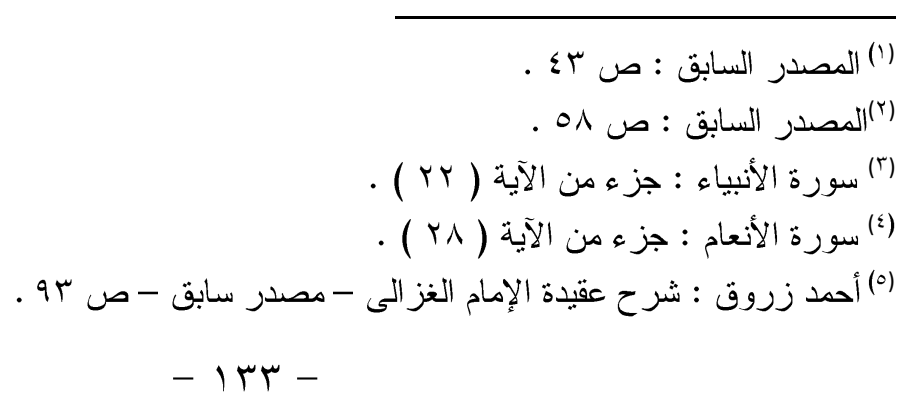


ج. صفة الإرادة : يقول زروق الإرادة يعنى ذكر أحكامها وما يتعلق بها من إثبات

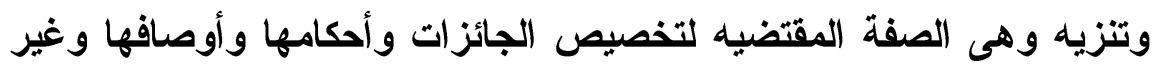

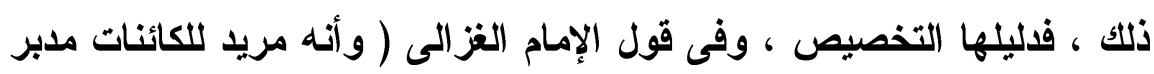

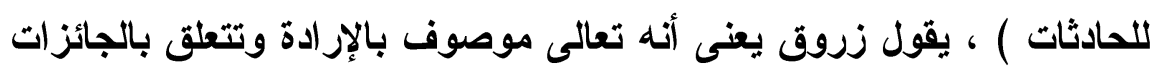

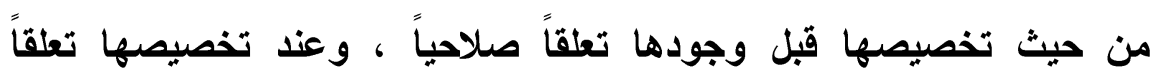

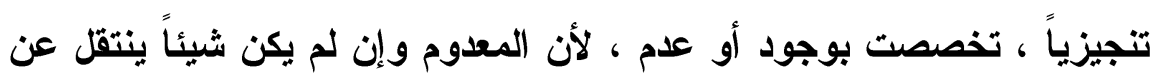

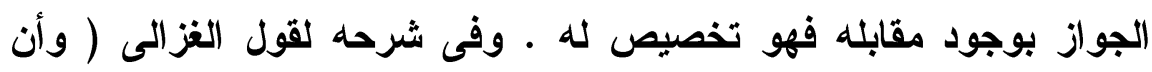

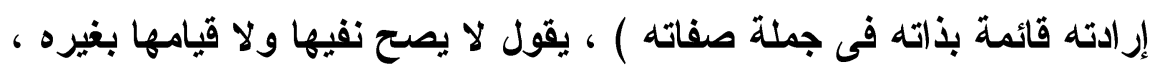

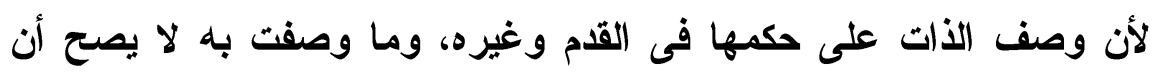

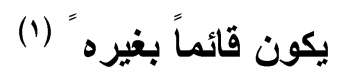
د. السمع والبصر : يقول زروق : السمع والبصر صفتان من صفاته المعنوية

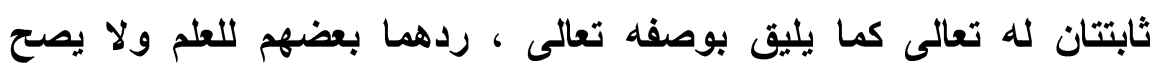

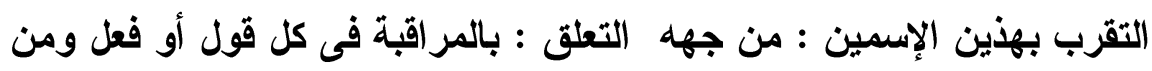

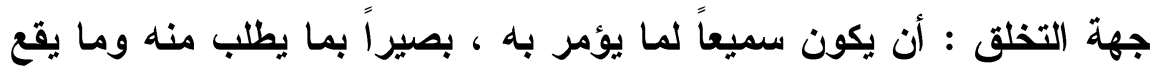

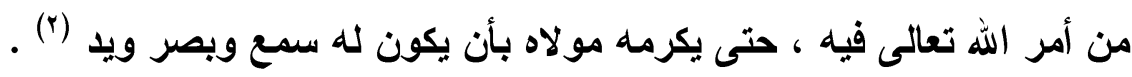

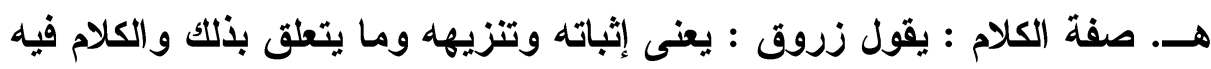

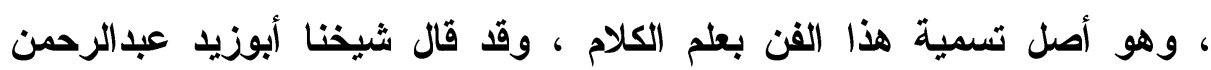

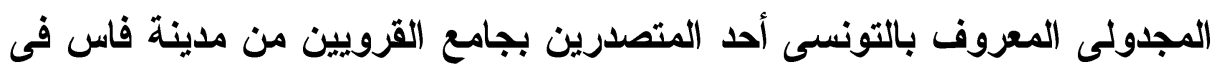
علم الأصول فى عصره وعنه أخذ أكثر أهلها فى وقته : سمعت شيخنا أبا عبدالله

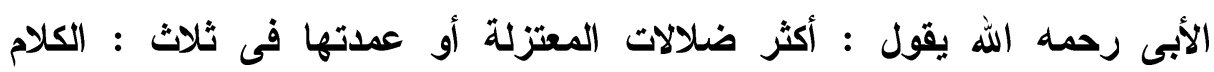

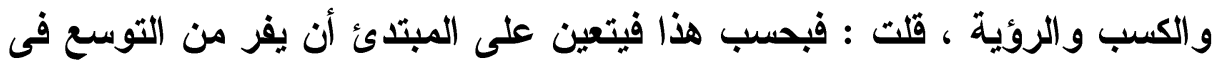

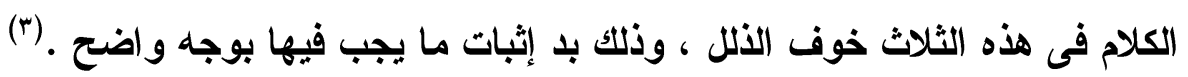

$$
\begin{aligned}
& \text { (1) المصدر السابق : ص } 91 \text { (1) . }
\end{aligned}
$$

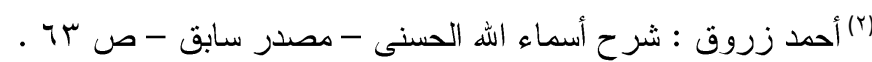

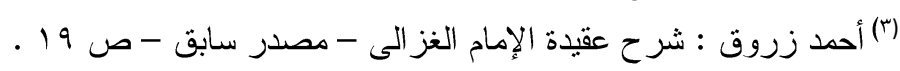

$$
\begin{aligned}
& -1 \text { IT - }
\end{aligned}
$$


r. الصفات المعنوية : وهى الألفاظ الدالة على معان قائمة بذات الله تعالى وهى

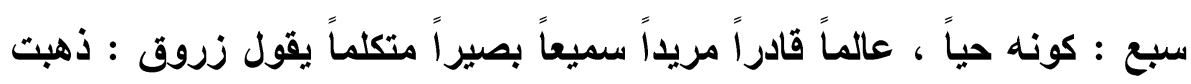

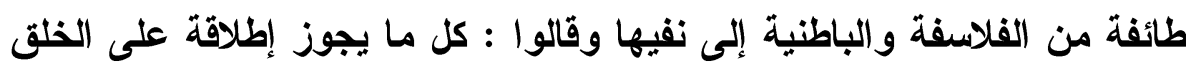
لا يجوز إطلاقه على الخالق بالإثبات ، وجوزوه بالنفى حتى امتنع بعضهم عن إنى

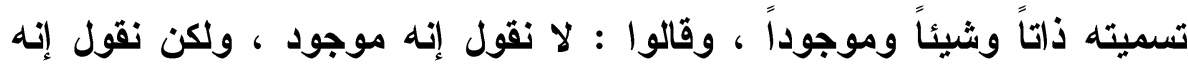

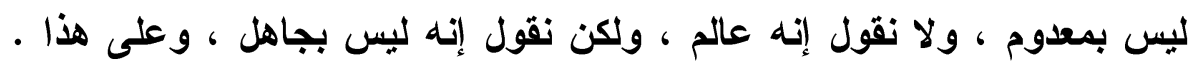

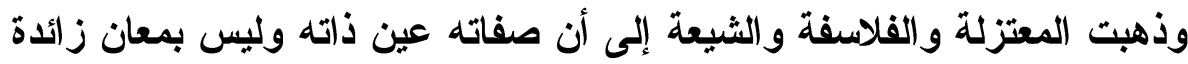

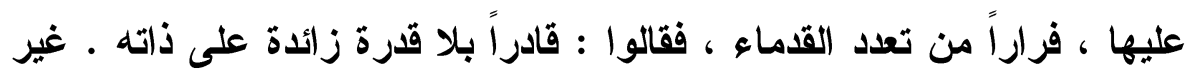
أن المعتزلة قالوا : كلامه وإرادته زائدتان على ذاتهاته، وزعموا أنهما حادثان

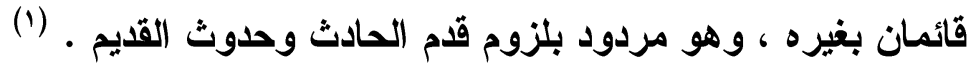

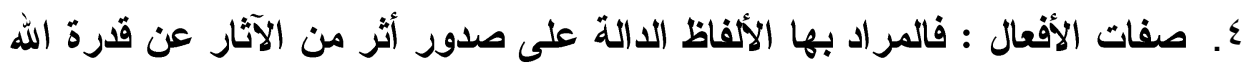

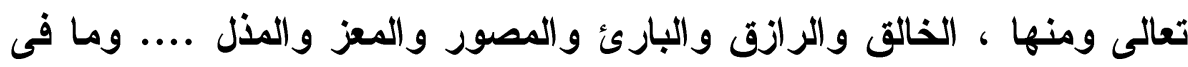

حكمها (r) (ن)

r. ما يتعلق بتنزيهه تعالى و أقسام الحكم العقلى : التزيه كما يقول زروق : يعنى التقديس والتطهير والترفيع والتعظيم والتحديد و التقدير ونحو ذلك من وجوه التنزيه الواجبه لله تعالى ، وهو ثابت بالدليل النقلى

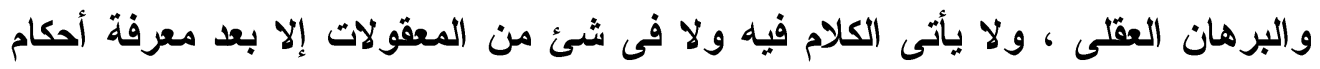

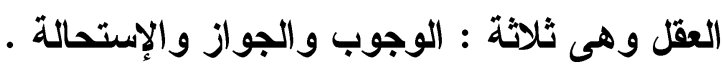

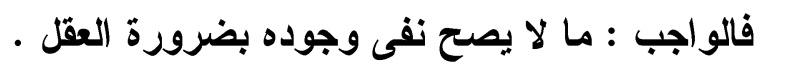

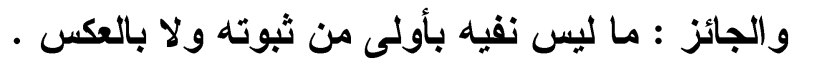
و المستحيل : ما لايصح إثباته ولا يتصور وجوده ، ثم هو على قسمين : محال

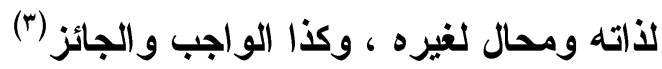

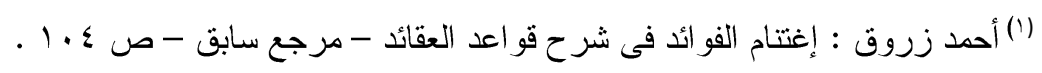

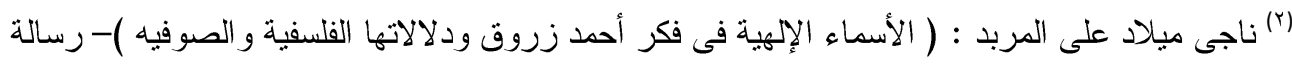

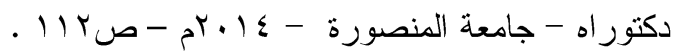

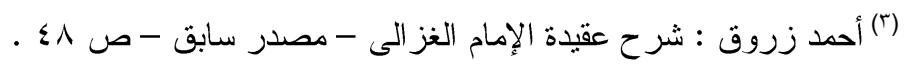




\section{ا ـ ـفى الحد والجهه عنه تعالى :}

يقول زروق فى شرحه لقول الإمام الغزالى ( وأنه تعالى لا يحده المقدار ، ولا تحويه

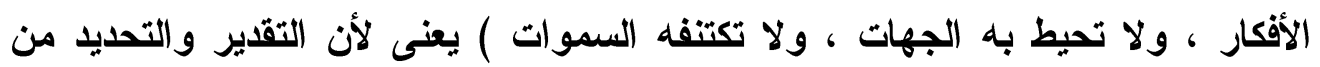

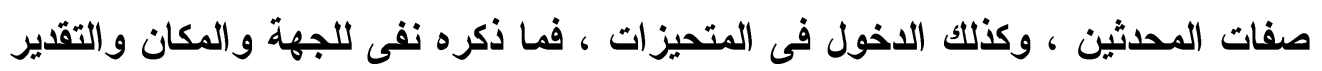

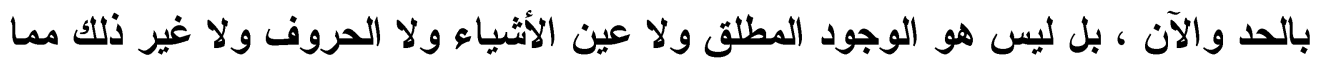

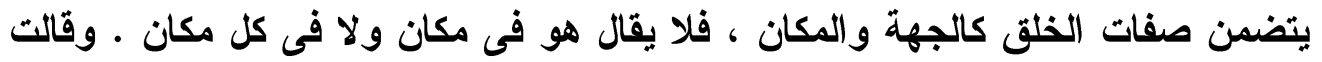

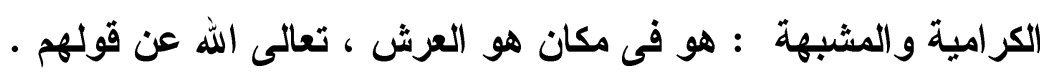

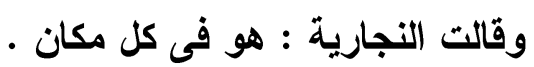

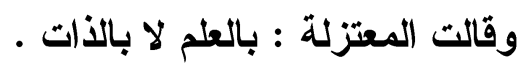
وفى حكم ابن عطاء الله رضى الله عنه : " الحق ليس بمحجوب وإنما المحجوب أنت عن النظر إليه ، إذ لو هو اين عطاء حجبه شئ لستره ما حجبه ، ولو كان له ساتر لكان لوجوده حاصر ، وكل حاصر لشئ

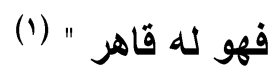

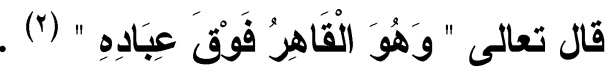

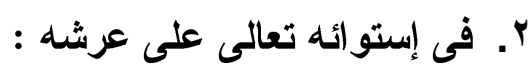

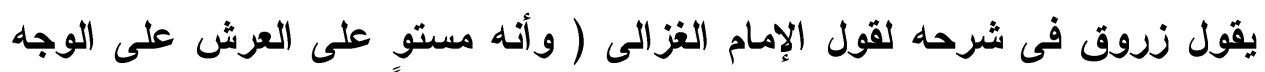

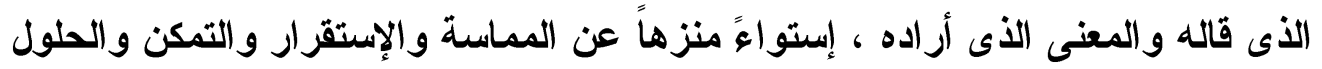

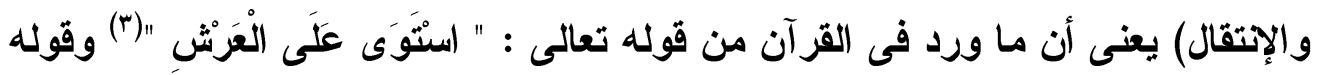

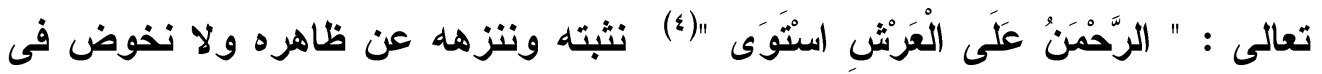

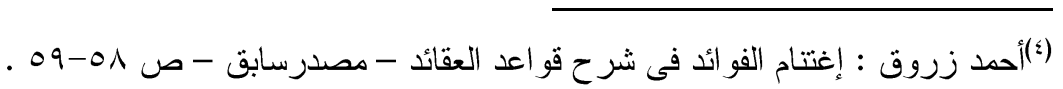

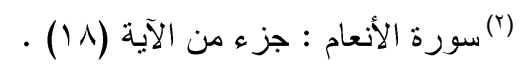

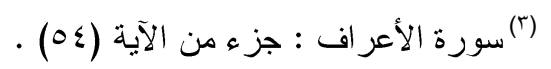

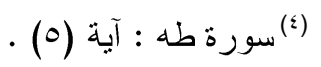

(") التنزيه: عبارة عن تبعيد الرب عن أوصاف البشر . انظر الجرجانى : معجم التعريفات - مرجع سابق -

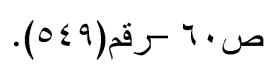

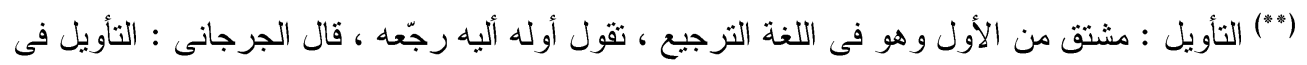

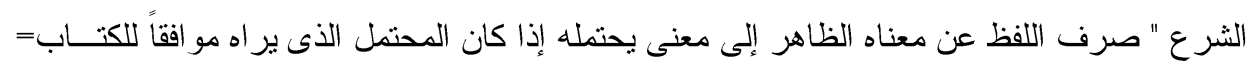


تأويله بل نفوض له تعالى فى شأنه أما إثباته فلثبوته بنص القرآن وأما التنزيه(") عن

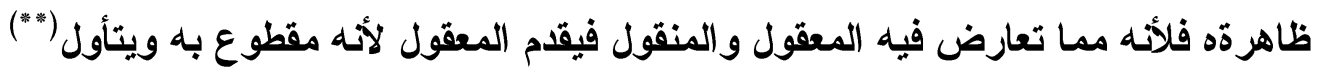
المنقول بما يحتمله من الوجه الصحيح فيه (') .

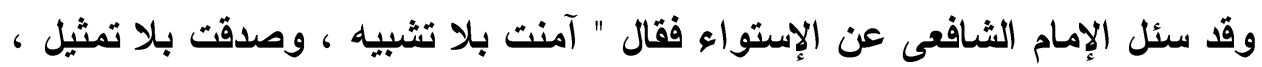
و إتهمت نفسى فى الإدرالك ، وأمسكت عن الخوض فيه كل الإمساك " وكذلك سئل الإمام ألهام

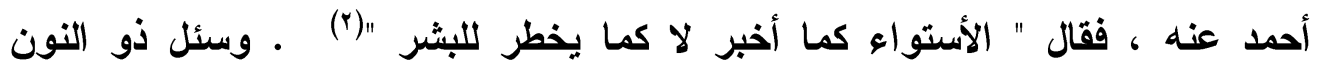

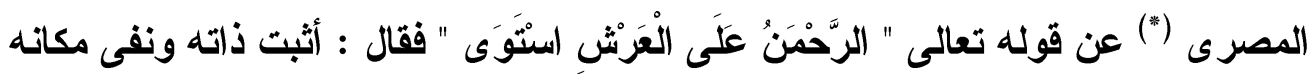

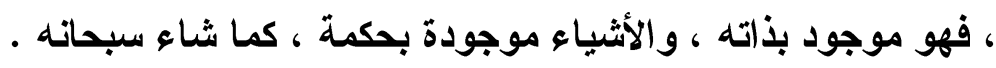

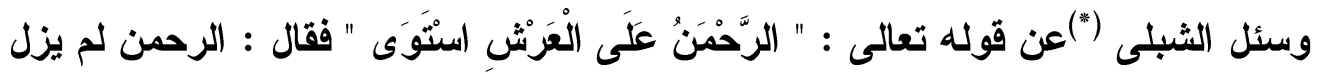
، والعرش محدث والعرش بالرحمن استوى ، وسئل جعفر بن نصير عن قوله تعالى :

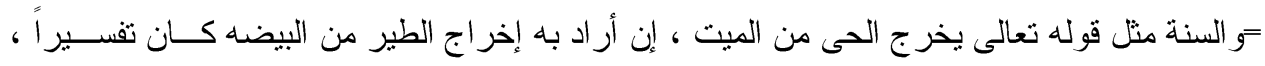

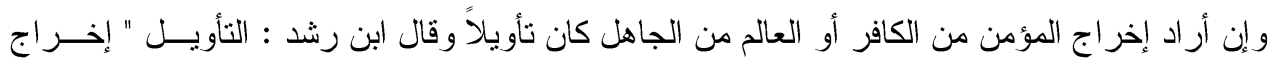

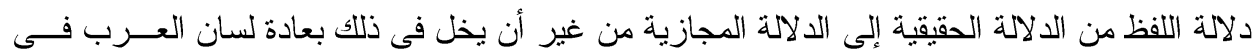

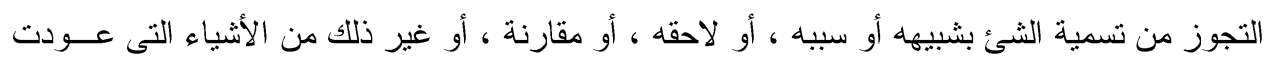

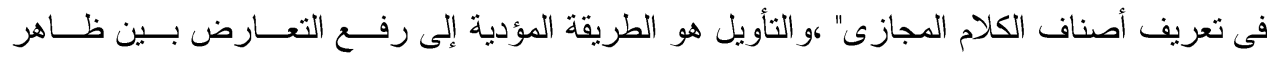

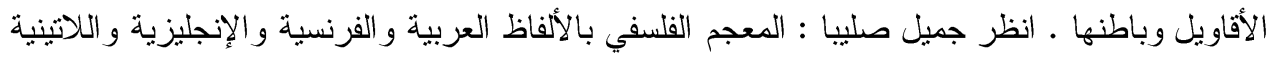

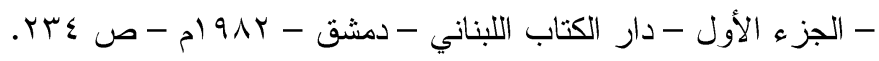

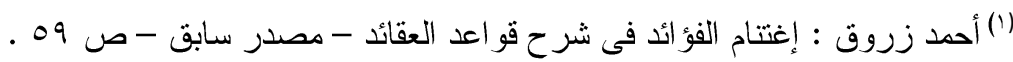

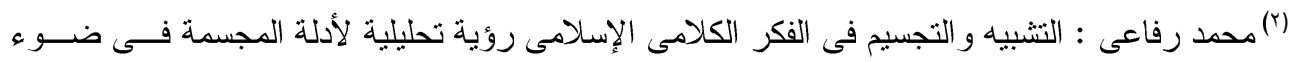

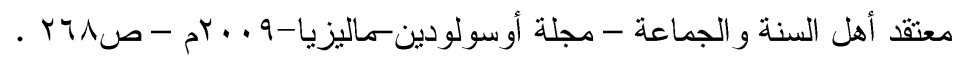

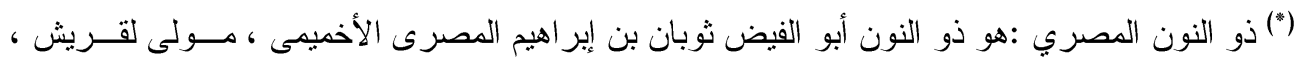

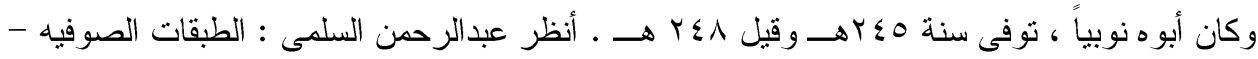

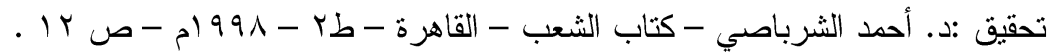

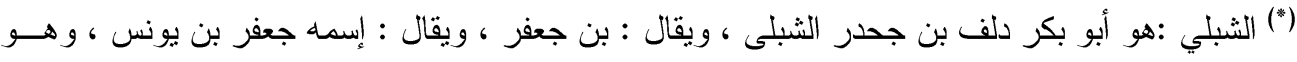

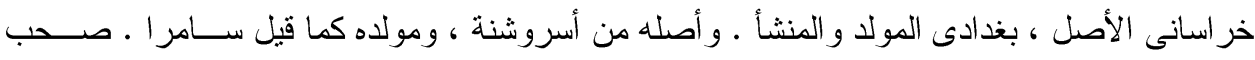

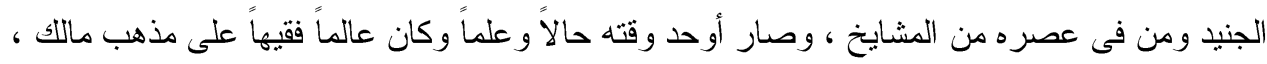

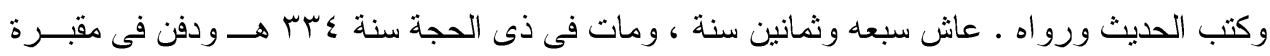

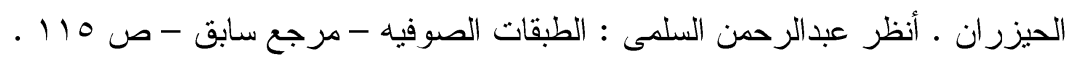




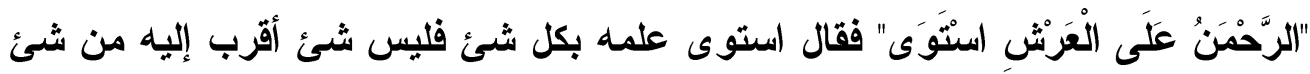

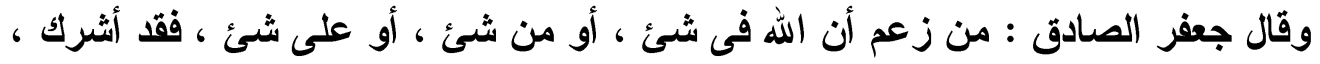

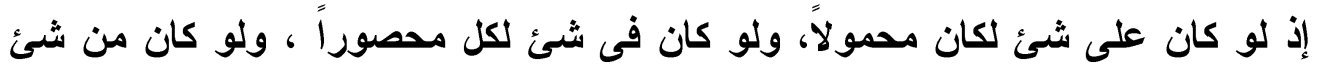

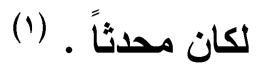

$$
\begin{aligned}
& \text { r. الكلام على الفوقية والقرب : }
\end{aligned}
$$

لقد شاع فى لغة العرب استخدام كلمة " فوق " فوقيه المرتبة والمنزلة ، يقال " الرئيس فوق الوزير " أو " العلم فوق العمل " ، لا يفهم منه عالم بأساليب اللغة العربية

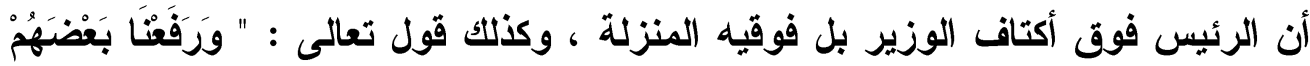

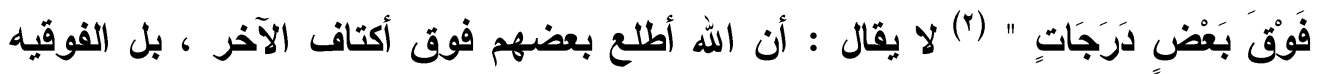

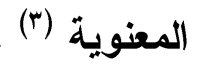
يقول زروق : يعنى فوق العرش فوقيه معنوية كما يقال : السلطان فوق الوزير

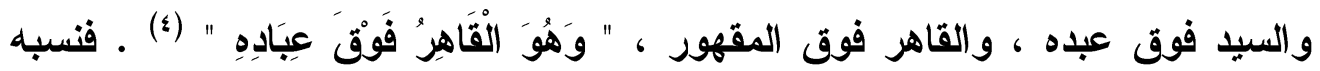

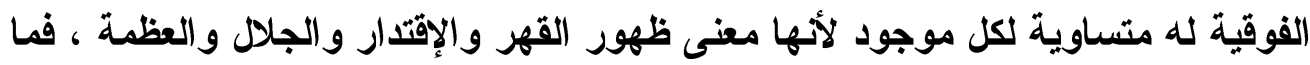
فوق السموات العلى فى ذلك كما تحث الثرى لأن ما سوى ذللك حادث دال مال على الحدوث

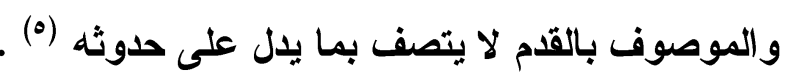

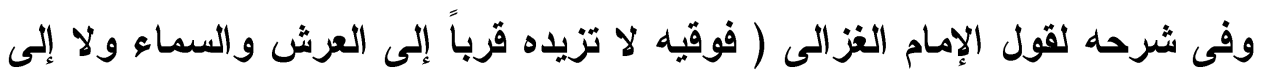
العرش والثرى ) يقول فهو قريب غير محسوس ولا يتوهم بل هو رفيع الدرجات عن العرش كما أنها

رفيع الارجات بالمعنى عن القرى ، لأن الكل يقتضى الجهة وهو تعالى منزه عن

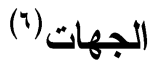

(1) أبى القاسم القشيرى : الرسالة القشيرية فى علم التصوف - تحقيق : هانى الحاج- دار التوفيقية للطباعة

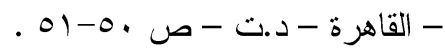

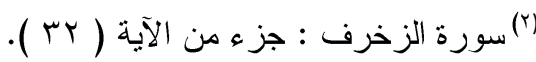

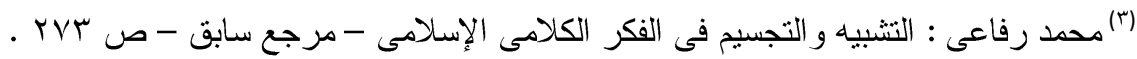

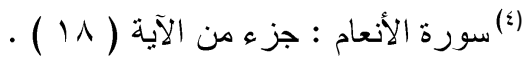

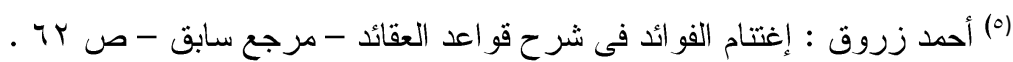

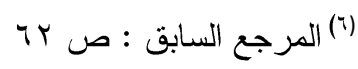


؛. فى نفى الحلول والإتحاد عن الله تبارك وتعالى :

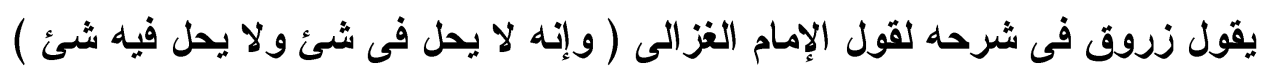

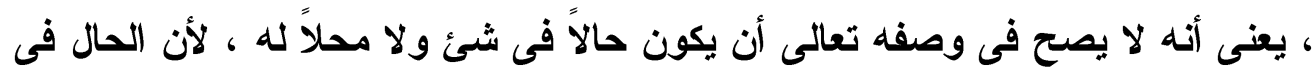

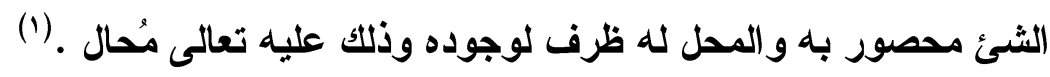
•. تنزهd تعالى عن المكان و الزمان :

فالله سبحانه وتعالى منزه عن أن يوصف بالإستقرار على العرش ، بـن ، تعالى على أن يحويه مكان كما تقدس على أن يحده زمان - أما تقدسه سبحانه وتعالى على المكان

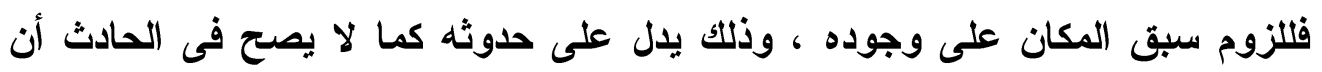

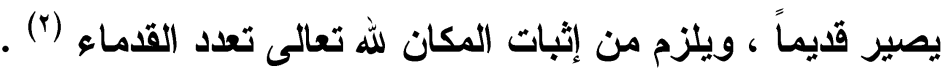

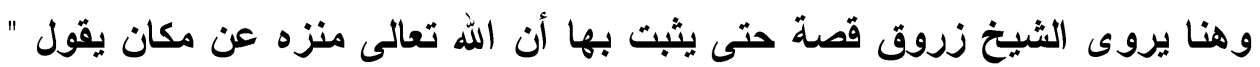

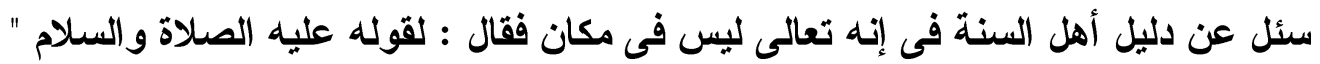

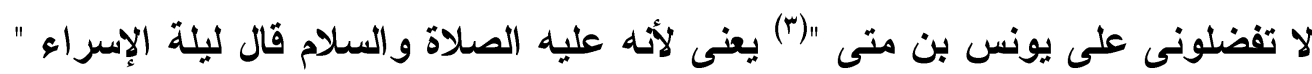

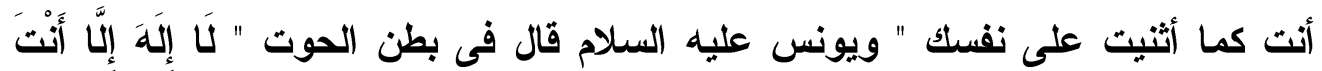

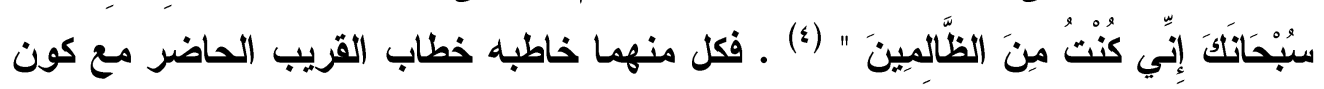

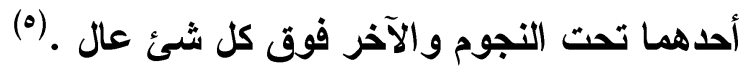

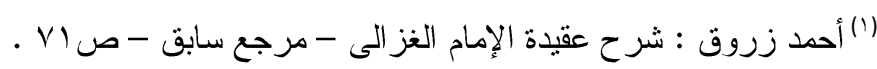

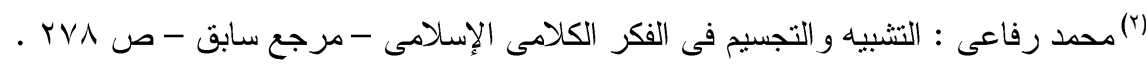

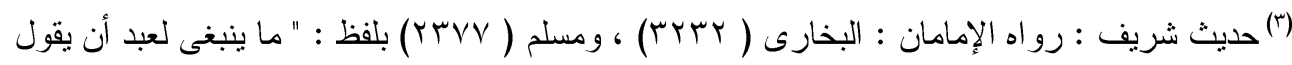

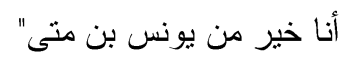

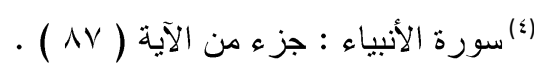

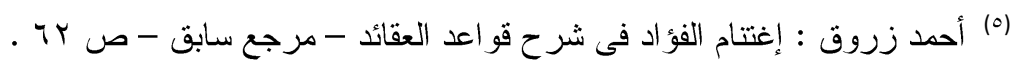


: خاتمة : (2)

بعد الإتتهاء من دراسة الألهيات عند الثيخ أحمد زروق والتى تتمثل فى التوحيد

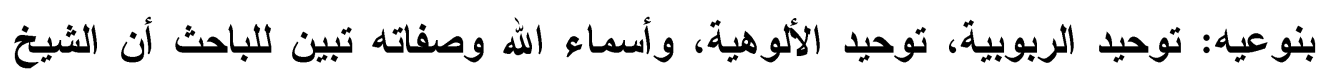

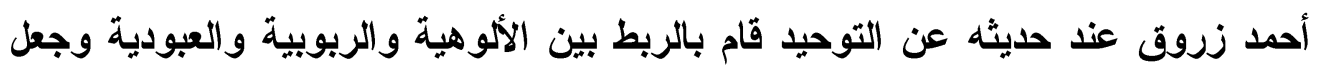
كل منهم وقف على الأخرى. كذلك يتضح من خلال هذا البحث أن أراء الثيخ أحمد زروق فى الأسماء والصفات

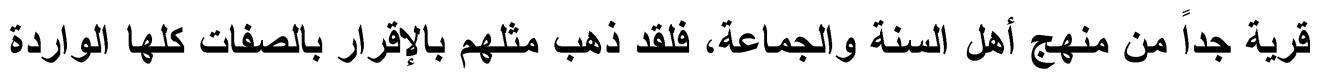
فى القرآن دون تثبيه أو تعطيل أو تأويل، واتقق معهم أيضاً فى أن أسماء الله وصفاتهاته توقيفيه أى يتوقف فيها على ما جاء به الكتاب والسنة.

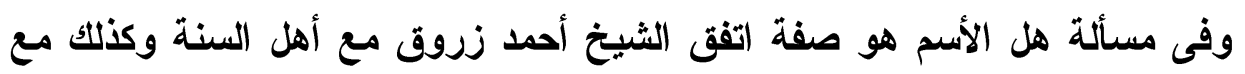
المذهب الأثشعى فى القول أن الاسم ليس هو الصفة بل أن كل اسم يثنمل على صفة

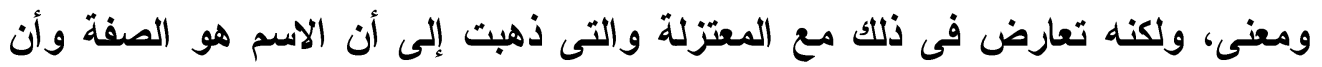
الأسماء أعلام لا أوصاف لها. 


$$
\begin{aligned}
& \text { فهرس المصادر والمراجع } \\
& \text { اولاً: المصادر } \\
& \text { أ- القرآن الكريم. } \\
& \text { ب- الأحاديث النبوية. } \\
& \text { ج- مؤلفات الشيخ أحمد زروق . الادئه }
\end{aligned}
$$

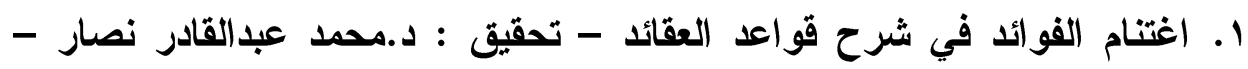

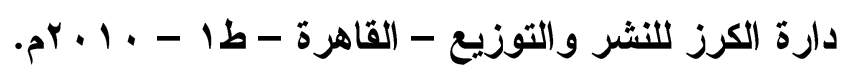

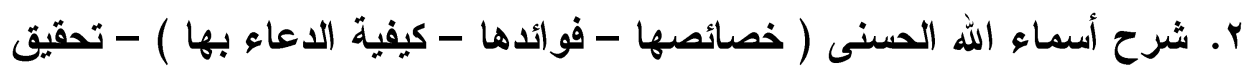

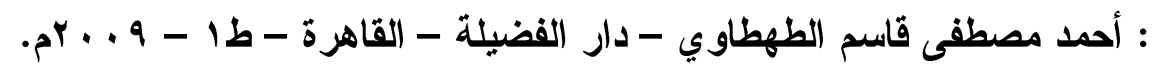

r. شرح العكم العطائية - تحقيق أبو سهل نجاح عوض صيام - دار المقطم للنشر

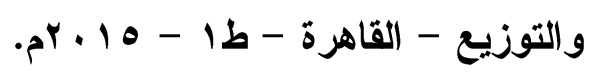

؛. شرح عقيدة الإمام الغزالي - تحقيق: د. محمد عبد القادر نصار - قدم له :

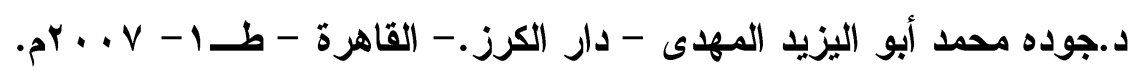

\section{ثانياً:المر (جع

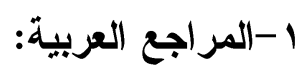

1. ابن القيم الجوزية (الإمام شمس الدين أبي عبد الله محمد بن أبي بكر بن أيوب)

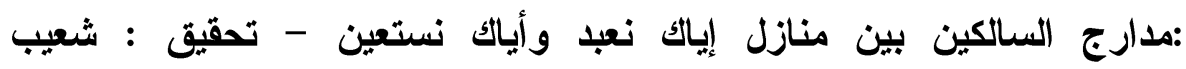

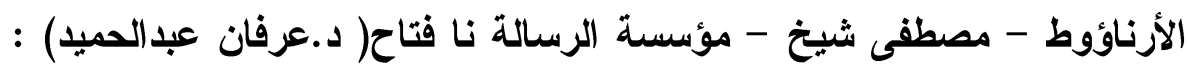

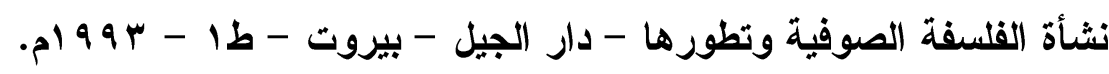
r. ابن الملقن(سراج الدين أبو حفص عمر بن علي ) ) : طبقات الأولياء-تحقيق

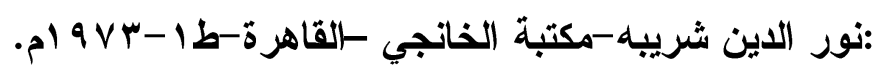
r. ابن خلكان(أبو العباس شمس الدين أحمد بن محمد) : وفئه البهات الأعيان وأنباء

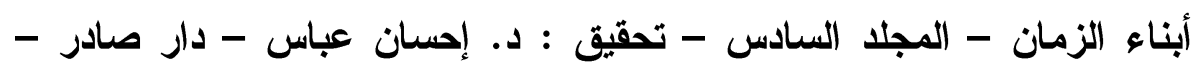

$$
\text { بيروت-9VV ام. }
$$


؛. بهجت( أحمد): الله في العقيدة الإسلامية - رسالة جديدة في التوحيد - مركز

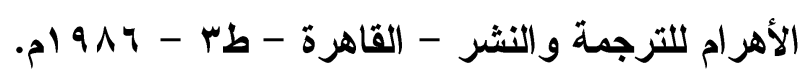

ه. الجامي (د.محمد أمان بن علي) : مجموع رسائل الجامي في العقيدة والسنة - دانئ

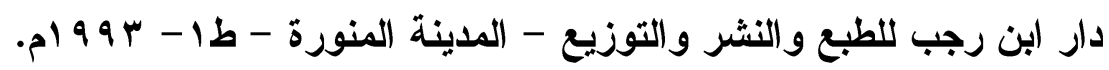

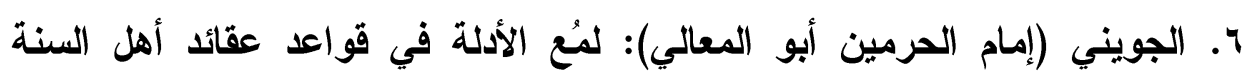

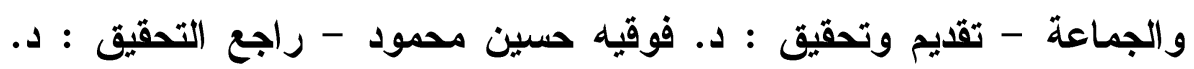

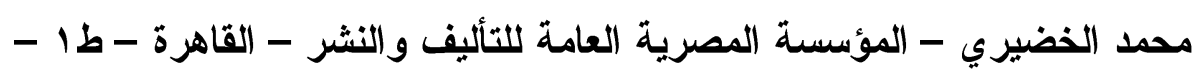

$$
\text { . } 1970
$$

V. خثيم ( د.على فهمى ):أحد زروق والزروقية- دراسة حياة وفكر ومذهب

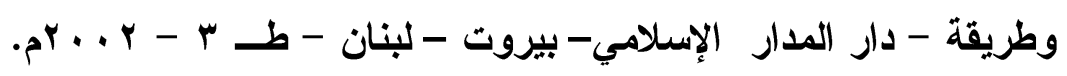

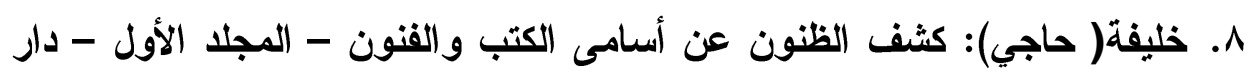

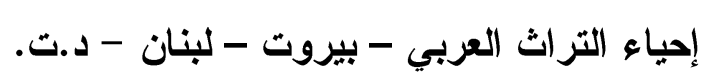

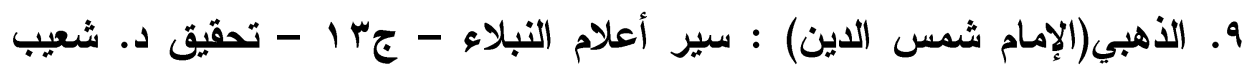

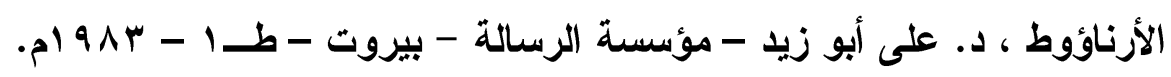

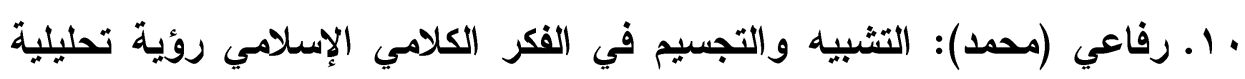
لأدلة المجسمة في ضوء معتقد أهل السنة والجماعة - مجلة أوسولودين-

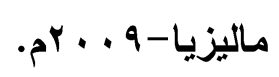

11 ـ سعيد(عبدالرحمن محمد) : موسوعة أهل السنة في نقد أصول فرقة الأحباش

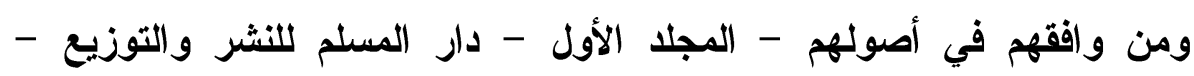

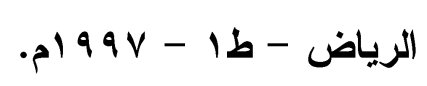

r ا. السُّلمى (أبو عبدالرحمن: الطبقات الصوفية - تحقيق :د. أحمد الثرباصي -

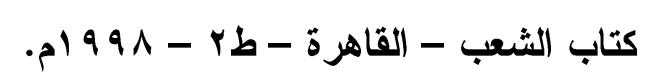

rا اـ الثافعي( أبو الحسن على الماوردي ): أعلام النبوة - دار الكتب العلمية -

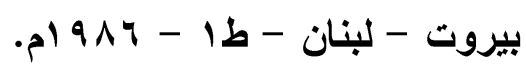

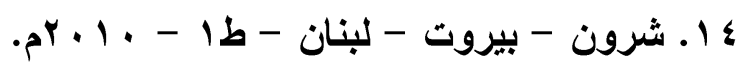


1. الطوسي (أبو نصر السراج ):اللّئع - تحقيق : د.عبدالعليم محمود ،د.طه

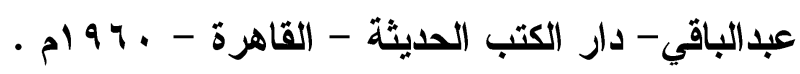

17 ا. عويس( منصور محمد): ابن تيميه ليس سلفياً - دار النهضة العربية -

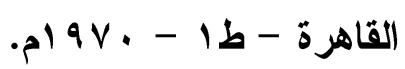

IV علم التصوف - تحقيق : هاني الحاج- دار التوفيقية للطباعة - القاهرة - د.ت.

$$
\text { r - المراجع الأجنبية }
$$

1- R.A.Nicholoson : Studies in Islamic Mysticism - Cambridge .press - 1921

ثالثاً: المعاجم و الموسوعات

1. الجرجاني(علي بن محمد السيد الثريف): معجم التعريفات - تحقيق محمد

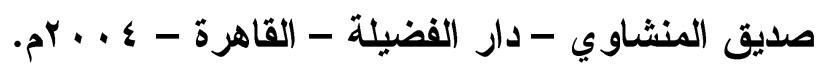

r. الزوبي( ممدوح) : معجم الصوفية - دار الجيل - بيروت - طا - ع ـ . . بم.

r. صليبا(د. جميل ): المعجم الفلسفي بالألفاظ العربية والفيل الفرنسية والإنجليزية

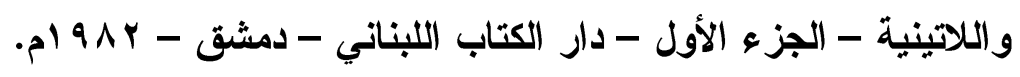

؛. العجم (د. رفيق): موسوعة مصطلحات التصوف الإسلامى - مكتبة لبنان

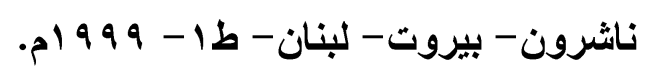

ه. فالح( أبو عبد الله عامر عبد الله): معجم ألفاظ العقيدة - تقديم: فضيلة الثيخ

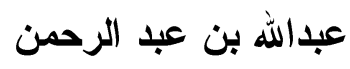

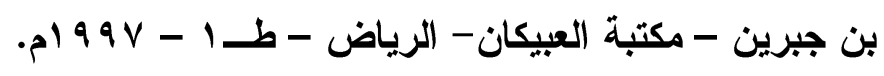

\section{رابعاً: الرسائل العلمية}

المربد(د. ناجى ميلاد على) : الأسماء الإهية في فكر أحد زروق ودلالتها الفلسفية

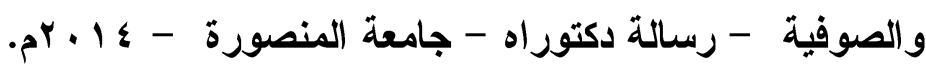

